\title{
Unsustainable Land Use, Sediment-Laden Runoff, and Chronic Raw Sewage Offset the Benefits of Coral Reef Ecosystems in a No-Take Marine Protected Area
}

\author{
Edwin A Hernandez-Delgado ${ }^{1,2,3}$ \\ ${ }^{1}$ University of Puerto Rico, Center for Applied Tropical Ecology and Conservation, \\ Puerto Rico, ${ }^{2}$ University of Puerto Rico, Department of Environmental Sciences, Puerto Rico; \\ ${ }^{3}$ Sociedad Ambiente Marino, San Juan, Puerto Rico
}

Jeiger L. Medina-Muñiz

Protectores de Cuencas, Inc., Yauco, Puerto Rico

Hernando Mattei

University of Puerto Rico, Medical Sciences Campus, Public Health Graduate School, San Juan, Puerto Rico

José Norat-Ramírez

University of Puerto Rico, Medical Sciences Campus, Public Health Graduate School, San Juan, Puerto Rico

Received: February 6, 2017 Accepted: July 2, 2017

doi:10.5296/emsd.v6i2.10687ＵRL: https://doi.org/10.5296/emsd.v6i2.10687

\begin{abstract}
Unsustainable land uses may result in poor watershed management, increased soil erosion, poorly-planned urban development, increased runoff, and sewage pollution, creating an environmental stress gradient across coastal coral reefs. This study was aimed at: 1) Evaluating water quality within and outside the Canal Luis Peña Natural Reserve (CLPNR), Culebra Island, Puerto Rico; 2) Determining if there was any significant environmental stress gradient associated to land-based non-point source pollution; and 3) Characterizing shallow-water coral reef communities across the gradient. Strong gradient impacts associated
\end{abstract}


to sediment-laden and nutrient-loaded runoff pulses, in combination with non-point raw sewage pulses, and sediment bedload, impacted coastal coral reefs. Water quality showed significant spatio-temporal fluctuations $(\mathrm{p}<0.0001)$, largely responding to heavy rainfall and subsequent runoff pulses. Benthic community structure showed significant spatial variation along the environmental stress gradient $(\mathrm{p}=0.0002)$. Macroalgae, dead coral surfaces, algal turf, and low coral species richness, species diversity index $\left(\mathrm{H}^{\prime} \mathrm{c}\right)$, and evenness (J'c) dominated benthic assemblages across reefs frequently impacted by runoff pulses and sediment bedload. The combination of fecal coliform and enterococci concentrations were correlated with variation in benthic community structure ( $R h o=0.668 ; p=0.0020)$. The combined variation in salinity, dissolved oxygen and enterococci concentrations explained $75 \%$ of the observed spatial variation in benthic assemblages $\left(R^{2}=0.7461 ; p=0.0400\right)$. Local human stressors affected coral reefs within no-take CLPNR and risk analyses suggest it may offset its ecological benefits. There is a need to design and implement integrated coastal-watershed management strategies to address multiple land use activities, including erosion-control best management practices, watershed reforestation, and sewage pollution control.

Keywords: Coral reefs, Environmental stress gradient, Land-based source pollution, Multivariate analyses, Regime shift, Runoff pulses, Tropical islands, Sewage pollution

\section{Introduction}

\subsection{Synergistic Impacts of Local and Global-Scale Factors in Coral Reef Decline}

Long-term degradation of coral reef ecosystems has largely resulted from a combination of human factors, including those with local scale impacts, such as poor land use (Sladek-Nowlis, Roberts, Smith \& Siriila, 1997; Ramos-Scharrón, Amador \& Hernández-Delgado, 2012; Ramos-Scharrón, Torres-Pulliza \& Hernández-Delgado, 2015), sedimentation (Pastorok \& Bilyard, 1985; Rogers, 1990), eutrophication (Cloern, 2001; Díaz-Ortega \& Hernández-Delgado, 2014; Ennis, Brandt, Grimes \& Smith, 2016), sewage pollution (Bonkosky, Hernández-Delgado, Sandoz, Robledo et al., 2009; Hernández-Delgado, Sandoz, Bonkosky, Mattei et al., 2010), and fishing (Hawkins \& Roberts, 2004). Also, large scale, climate change-related sea surface warming (Hoegh-Guldberg, 1999; Li \& Reidenbach, 2014), massive coral bleaching (Miller, Muller, Rogers, Waara et al., 2009), mass coral mortalities (Miller, Waara, Muller \& Rogers, 2006), and ocean acidification (Pandolfi, Connolly, Marshall \& Cohen, 2011) have resulted in significant biodiversity loss (Jones, McCormick, Srinivasan \& Eagle, 2004) and in the alteration of ecosystem functions (Bellwood, Hughes, Folke \& Nyström, 2004), benefits (Veron, Hoegh-Guldberg, Lenton, Lough et al., 2009), and resilience (Carilli, Norris, Black, Walsh et al., 2009; Elmhirst, Connolly \& Hughes, 2009; Anthony, Maynard, Díaz-Pulido, Mumby et al., 2011). Large-scale, climate change-related phenomena often operate atop of multiple local scale factors, which in combination, can often magnify local impacts on coral reef ecosystem resilience (Hughes, Rodrigues, Bellwood, Ceccarelli et al., 2007; Ledlie, Graham, Bythell, Wilson et al., 2007; Vega-Thurber, Burkepile, Fuchs, Shantz et al., 2013; Duprey, Yasuhara \& Baker, 2016) and on overall biodiversity (Foden, Maze, Vié, Angulo et al., 2008; Bellard, 
Bertelsmeier, Leadley, Thuiller et al., 2012; Rogers, 2013).

Multiple studies have shown that the state of coral reef decline is significant across very large spatial scales (Gardner, Côtè, Gill, Grant et al., 2003; Côtè \& Darling, 2010). It is affecting multiple reef-building taxa (Rogers \& Miller, 2006; Miller, Muller, Rogers, Waara et al., 2009; Edmunds, 2013) and fish biodiversity (Jones, McCormick, Srinivasan \& Eagle, 2004; Paddack, Reynolds, Aguilar, Appeldoorn et al., 2009; Pratchett, Hoey, Wilson, Messmer et al., 2011; Jackson, Donovan, Cramer \& Lam, 2014). Coral reefs are showing limited recovery (Gardner, Côtè, Gill, Grant et al., 2005), with natural benthic community trajectories favoring dominance by non-reef building corals (Edmunds \& Elahi, 2007; Hernández-Delgado, González-Ramos \& Alejandro-Camis, 2014). Modeling efforts suggest further coral reef decline in the near future under current trends of environmental and climate-related change (Buddemeier, Jokiel, Zimmerman, Lane et al., 2008; Buddemeier, Lane \& Martinich, 2011; Hernández-Pacheco, Hernández-Delgado \& Sabat, 2011; Hoeke, Jokiel, Buddemeier \& Brainard, 2011; Freeman, Kleypas \& Miller, 2013). This can further compromise ecosystem resilience, functions and services (Veron, Hoegh-Guldberg, Lenton, Lough et al., 2009). Therefore, coral reef conservation efforts need to extend beyond the coral reef boundaries and the shoreline up into adjacent watersheds to enhance the ability to recover coral reef ecosystem resilience (Shelton \& Richmond, 2016).

Poor and unsustainable land uses, in combination with rainfall pulse events, represent a major concern for the conservation and natural recovery of coral reefs (Otaño-Cruz, Montañez-Acuña, Torres-López, Hernández-Figueroa et al., 2017). Activities such as deforestation and construction of unpaved roads across steep slopes have resulted in increasing soil erosion rates and subsequent sediment delivery to adjacent coastal habitats (Sladek-Nowlis, Roberts, Smith \& Siirila, 1997; MacDonald, Anderson, \& Dietrich, 2007), with concomitant long-term impacts on adjacent coral reef ecosystems (Nemeth \& Sladek-Nowlis, 2001; Ramos-Scharrón, Amador, \& Hernández-Delgado, 2012; Ramos-Scharrón, Torres-Pulliza, \& Hernández-Delgado, 2015). Increasing sedimentation is often linked to increasing turbidity and eutrophication (Meesters, Bak, Westmacott, Ridgley et al., 1998). The combination of increasing eutrophication and sea surface temperature (SST) has been implicated in magnifying coral bleaching severity (Vega-Thurber, Burkepile, Fuchs, Shantz et al., 2013) and coral reef decline (Carilli, Norris, Black, Walsh et al., 2009; Anthony, Maynard, Díaz-Pulido, \& Mumby, 2011). Improving the conservation of watersheds and the implementation of sustainable land use strategies have become paramount for the conservation and rehabilitation of coral reef ecosystems in the context of climate change. Reducing local impacts may contribute to ameliorate potential impacts from other large-scale factors such as increasing SST.

\subsection{Declining Coral Reef Ecosystems in Puerto Rico}

The island of Puerto Rico, located in the northeastern part of the Caribbean Sea, has the largest population density of the Greater Antilles. It has been subjected to extensive non-sustainable development practices, providing multiple case studies to address the ecological consequences of unsustainable land uses on coastal ecosystems 
(Hernández-Delgado, Ramos-Scharrón, Guerrero, Lucking et al., 2012). Coastal water quality in Puerto Rico has been implied in long-term coral reef decline (Goenaga \& Cintrón, 1979; Hernández-Delgado \& Sabat, 2000; García-Saís, Morelock, Castro, Goenaga et al., 2003; García-Saís, Appeldoorn, Batista, Bauer et al., 2008; Hernández-Delgado, 2005; Ballantine, Appeldoorn, Yoshioka, Weil et al., 2008). Major threats to coastal water quality include high sediment loads (Rogers, 1990), excess nutrient inputs (Tomascik, 1990), marine snow associated to turbid water pulses (Fabricius \& Wolanski, 2000), sewage and non-point source pollutants (Bonkosky, Hernández-Delgado, Sandoz, Robledo et al., 2009). Recent evidence shows rapidly declining coastal coral reefs from a combination of sewage and eutrophication impacts (Hernández-Delgado, Sandoz, Bonkosky, Mattei et al., 2010; Díaz-Ortega \& Hernández-Delgado, 2014), and from sediment delivery following rainfall and runoff pulse events (Otaño-Cruz, Montañez-Acuña, Torres-López, Hernández-Figueroa et al., 2017). The chronic combination of many of these factors can trigger long-term changes in coral reef benthic assemblages, with strong gradient effects.

The impact of local stressors will depend on the environmental history and on factors such as the spatial distribution of human population centers, river mouths, sewage outfalls, non-point pollution sources, and coastal currents, as well as factors variable in time, such as storm-induced damage and runoff, continued coastal development, and fishing. These factors often create variable chronic anthropogenic stress gradients, usually negatively affecting water quality (Tomascik \& Sander, 1985), coral growth rates (Tomascik, 1990), coral disease prevalence (Kaczmarsky, Draud \& Williams, 2005; Smith, Nemeth, Blondeau, Calnan et al., 2008), partial colony mortality (Nugues \& Roberts, 2003), and coral reef benthic community structure (Fabricius \& McCorry, 2006). Current state of coral reef decline represents an increasing threat to coastal communities from climate change and sea level rise (Hernández-Delgado, 2015). As a consequence, the condition of coral reefs around Puerto Rico shows a large degree of spatio-temporal variability over the long term. But such variability has been poorly documented due to significant limitations of previous long-term monitoring efforts.

Sediment-laden runoff, raw sewage, landfill and pier operations in Culebra Island, northeast Puerto Rico, have been identified among the most significant environmental threats to marine communities located within the Canal Luis Peña No-Take Natural Reserve (CLPNR) (Hernández-Delgado, 2003b, 2004). However, such impacts, although qualitatively documented, have never been quantified in the past. Biological communities within CLPNR support an outstanding biodiversity representative of the northeastern Caribbean region (Hernández-Delgado, 2000, 2003a; Hernández-Delgado, Alicea-Rodríguez, ToledoHernández \& Sabat, 2000; Hernández-Delgado \& Rosado-Matías, 2003). But coral reefs within and outside CLPNR have shown significant signs of decline over the last two decades (Hernández-Delgado, Rosado-Matías, \& Sabat, 2006; Hernández-Pacheco, HernándezDelgado, \& Sabat, 2011). Long-term changes have been attributed to the combined impact of water quality decline and sea surface warming, making a key priority to quantitatively address the impacts of local land use patterns on adjacent coral reef benthic community structure to understand the potential of natural and assisted recovery and rehabilitation in face 
of increasing impacts by climate change.

\subsection{Objectives}

This study was aimed at: 1) Evaluating the physical and microbiological water quality conditions within and outside the CLPNR; 2) Determining if there was any significant environmental stress gradient associated to land-based non-point source pollution; and 3) Characterizing shallow-water coral reef communities across the gradient. This constitutes a representative case study of Caribbean coral reef ecosystems impacted by multiple factors associated to unsustainable land use practices.

\section{Materials and Methods}

\subsection{Water Quality Sampling Sites}

Water quality sampling was conducted across 10 sampling sites located along a suspected environmental stress gradient from Ensenada Honda Bay towards Luis Peña Channel, in Culebra Island, Puerto Rico (Figure 1). Six out of ten water quality sampling sites were located within CLPNR. According to Capella (2004), predominant sea surface currents around Culebra have an along-isobath flow in the axis $300^{\circ} \leftrightarrow 120^{\circ}$ true. Further, there are strong semidiurnal (two cycles per day), and weaker diurnal (one cycle per day) tidal components, with maximum amplitudes of $20-30 \mathrm{~cm} / \mathrm{s}$, but that can occasionally reach as much as $40-50 \mathrm{~cm} / \mathrm{s}$. Northwestward flow towards $300^{\circ}-320^{\circ}$ true occurs during the flooding tide (as the sea surface elevation is increasing), whereas the ebbing tide coincides with southeastward flow $120^{\circ}-140^{\circ}$ true. Strongest currents were detected during flooding tide, which suggests that poor water quality pulses flow from Ensenada Honda Bay and Lobina Channel in the downtown area during ebbing tide towards Bahía Sardinas. Waters are subsequently carried out to the west and then northwest, through the Luis Peña Channel towards CLPNR, during the flooding tidal cycle. Therefore, sampling sites were selected following the suspected impact of recurrent pulses of non-point source pollution through this along-isobath flow within CLPNR.

Predominant benthic communities at each water quality sampling site were as follows: CLA= muddy bottom, sporadic seagrass, macroalgal plain; MPI= muddy bottom, sporadic seagrass; $\mathrm{LOB}=$ muddy bottom, low cover macroalgal plain; $\mathrm{BSA}=$ muddy bottom, seagrass, coral reefs; PME, PTC, AEB, PRA= coral reefs, colonized pavement, seagrass, sand bottom; and $\mathrm{CLP}, \mathrm{PCR}=$ coral reefs, colonized pavement, sand bottom. CLA, MPI, and LOB receive recurrent impacts of raw sewage, as well as sediment- and nutrient-laden runoff pulses from urbanized areas during heavy rainfall events. BSA receives occasional non-point source pollution from similar sources, as well as recurrent pulses of polluted waters from Ensenada Honda and LOB during ebbing tide. PME receives occasional nutrient- and sediment-laden runoff pulses from illegal deforestation and culvert deviation towards the shore. AEB receives frequent nutrient- and sediment-laden runoff pulses from an adjacent poorly maintained access road and poorly managed developed areas. PRA receives occasional nutrient- and sediment-laden runoff pulses from a nearby road and a poorly managed landfill. PCR receives similar pulses from an unpaved and highly eroded abandoned dirt road, as well 
as from several small ephemeral creeks that empty into the shoreline. PTC and CLP are indirectly impacted by pollution pulses carried out from population centers by surface currents during tidal cycles. The Culebra Island Municipal Landfill is located adjacent to PRA ats CLPNR. CLPNR covers an area of approximately 636 ha, with depths reaching approximately $24 \mathrm{~m}$. Patchy macroalgal plains cover approximately $30 \%$ of the bottom, closely followed by continuous seagrass communities with 28\% (Hernández-Delgado, 2003). Colonized pavements cover nearly $20 \%$ of the bottom.

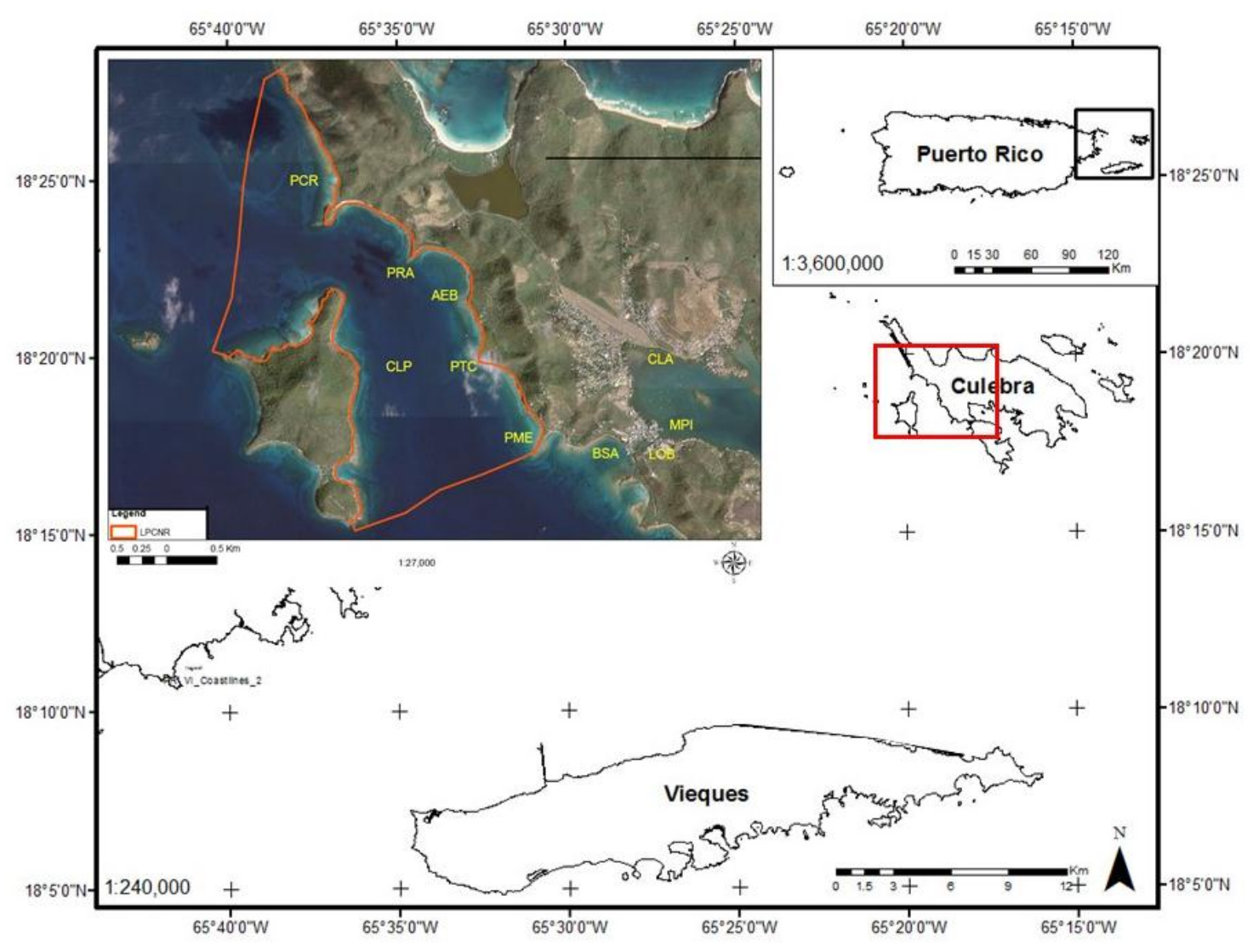

Figure 1. Study sites at Culebra Island, Puerto Rico: Barriada Clark (CLA); Municipal Pier (MPI); Lobina Channel (LOB); Bahía Sardinas (BSA*); Punta Melones (PME*); Punta Tamarindo Chico (PTC*); Arrecife El Banderote (AEB*); Punta Rompeanzuelo (PRA*); Playa Carlos Rosario ( $\mathrm{PCR}^{*}$ ); Cayo Luis Peña (CLP*). Orange polygon in the image insert delineates CLPNR. * $=$ Coral reef study sites

\subsection{Environmental Parameters}

Monthly measurements of SST, $\mathrm{pH}$, salinity (ppt), conductivity $(\mathrm{ms} / \mathrm{cm})$, and dissolved oxygen concentration $(\mathrm{mg} / \mathrm{L})$ were obtained in triplicates using a U10 Horiba Water Meter (Horiba Instruments, Kyoto, Japan) during the period of May to November. Triplicate lectures of water turbidity were obtained during each visit to study sites using a Hach portable turbidimeter. Turbidity data was expressed in nephelometric turbidity units (NTU). 


\subsection{Microbial Water Quality Analysis}

Grab water samples were collected at each study site using sterile Nalgene 1 L plastic bottles (Nalgene Co.). Samples were collected in duplicates at $30 \mathrm{~cm}$ below surface using sterilized gloves and immediately placed on ice until analyzed within 12-24 hr. Samples were analyzed following standard membrane filtration techniques to quantify fecal coliforms (FC) and enterococci (ENT) (APHA, 1992). Water samples were filtered onto cellulose acetate membranes $\left(0.45 \mu \mathrm{m}\right.$ pore), using MicroFunnel ${ }^{\mathrm{TM}}$ filter funnels (Pall, Co., Ann Arbor, MI). Volumes analyzed were $1 \mathrm{~mL}, 10 \mathrm{~mL}$, and $100 \mathrm{~mL}$, although variations were used as necessary, depending on source and water turbidity. Filters were washed with sterile $3 \%$ saline buffer solution after the desired volume was filtered.

FC were quantified using $m F C$ agar. Culture media was prepared by adding $52 \mathrm{~g} / \mathrm{L}$ to purified water and set at $\mathrm{pH}$ of $7.4 \pm 0.2$, heated. After boiling, $10 \mathrm{ml} / \mathrm{L}$ of $1 \%$ rosolic acid solution $(0.5 \mathrm{~g}$ of rosolic acid/50 $\mathrm{ml}$ of $0.2 \mathrm{~N} \mathrm{NaOH})$ was added to prevent growth by non-coliform microbiota. The final mixture was poured in culture plates. Samples were incubated at $44.5^{\circ} \mathrm{C}$ for $24 \mathrm{hr}$. A positive result for this media was the presence of blue colonies due to the fermentation of lactose. Lauryl Triptose Broth (LTB) was used to confirm positive results using culture tubes containing inverted Durham tubes. This culture media also contains lactose and was prepared by adding $35.6 \mathrm{~g} / \mathrm{L}$ to water, and autoclaved for 15 minutes at $121^{\circ} \mathrm{C}$. Presumptive positive results were confirmed in LTB media and incubated at $35^{\circ} \mathrm{C} / 24 \mathrm{~h}$. Positive results produced turbidity and gas in the Durham tubes.

$M$ Enterococcus agar was used to grow ENT. Culture media was prepared by adding $42 \mathrm{~g} / \mathrm{L}$ to purified water and set at $\mathrm{pH}$ of $7.2 \pm 0.2$. Plates were incubated at $35^{\circ} \mathrm{C}$ for $48 \mathrm{hr}$. Intense pink and brown colonies indicated a positive result. Azide Dextrose Broth (ADB) was used as a confirmatory test to validate the presence of enterococci and to discard false positive results. ADB was prepared by dissolving $34.7 \mathrm{~g} / \mathrm{L}$ to water and autoclaved for fifteen minutes at $121^{\circ} \mathrm{C}$. Its final $\mathrm{pH}$ was set at $7.2 \pm 0.2$. Positive microorganisms were transferred to the tubes containing $\mathrm{ADB}$ and incubated for 24 hours at $35^{\circ} \mathrm{C}$. A positive result consisted of the presence of turbidity in the broth. Colonies concentration was expressed in colony forming units (CFU) per $100 \mathrm{~mL}$.

\subsection{Coral Reef Benthic Habitat Characterization}

Six random replicate $30 \mathrm{~m}$-long point-count transects were sampled with the use of digital video imaging ( $\mathrm{n}=60$ points/transect) across shallow zones $(2.5-4.5 \mathrm{~m})$ of each of the seven coral reef study sites (Figure 1). Data obtained included coral species richness, percent cover of benthic components, including coral, algal functional groups (e.g., macroalgae, filamentous algae, Halimeda spp., crustose coralline algae), sponge, cyanobacteria, and sand/pavement/rubble. Coral species diversity index (H'n) and evenness (J'n) were also calculated. In addition, recent and partial colony mortality were documented.

\subsection{Statistical Analyses}

We tested the null hypothesis of no significant difference in water quality parameters and microbial indicators among sites following a two-way permutational analysis of variance 
(PERMANOVA) using multivariate statistical package PRIMER 7.0.11 + PERMANOVA 1.16, with time and site as main variables (Anderson, Gorley \& Clarke, 2008). Time x site interaction was also tested. Environmental data were $\log _{10}$-transformed and normalized prior to analysis. Chapman non-linear regression was carried out to test the relationship between water turbidity and the concentration of indicator microorganisms. Principal coordinates ordination (PCO) was used to address clustering patterns of sampling sites and dates resulting from the spatio-temporal variation in environmental parameters. The null hypotheses of no significant difference in benthic community structure and other benthic parameters were assessed by means of a one-way PERMANOVA to address spatial variation patterns. A shade plot and PCO analyses were used to address spatial variation in benthic assemblages. A SIMPER routine was done to determine key taxa responsible for spatial variation in community structure between sites (Clarke, Gorley, Sommerfield, \& Warwick, 2014).

LINKTREE regression test was used to rank the relationship of environmental parameters and the observed spatial variation patterns in benthic community structure (Clarke, Gorley, Sommerfield \& Warwick, 2014). A distance-based linear model (DISTLM) using a distance-based redundancy analysis approach (dbRDA) was performed for multiple linear regression analyses to assess potential effects of environmental variables on benthic community structure, and coral diversity parameters (Anderson, Gorley \& Clarke, 2008). Arcview 10.2, in combination with water turbidity, FC, and ENT data, were used to generate a GIS-based model and maps to predict potential coastal water quality responses to runoff pulses around Culebra Island.

\section{Results}

\subsection{Spatio-temporal Patterns of Environmental Variables}

There was a highly significant difference in SST among sampling dates $(\mathrm{p}<0.0001)$, and among study sites $(\mathrm{p}<0.0001)$, and a significant time $\mathrm{x}$ site interaction $(\mathrm{p}<0.0001)$ (Table 1$)$. SST was significantly higher at CLA $\left(30.8^{\circ} \mathrm{C}\right)$, MPI $\left(29.9^{\circ} \mathrm{C}\right)$, and LOB $\left(29.5^{\circ} \mathrm{C}\right)$ (Figure $\left.2 \mathrm{a}\right)$. These sites were shallow grounds located in the inner part of Ensenada Honda Bay. SST was significantly higher during late summer months (September, October). There was also a highly significant difference in $\mathrm{pH}$ among sampling dates $(\mathrm{p}<0.0001)$, among study sites $(\mathrm{p}<0.0001)$, and a significant time $\mathrm{x}$ site interaction $(\mathrm{p}<0.0001)$ (Table 1). $\mathrm{pH}$ was significantly higher at CLA (8.32), MPI (8.29), and LOB (8.28), and showed significant declines during major runoff events from urban areas (Figure 2b). There was a highly significant difference in salinity among sampling dates $(\mathrm{p}<0.0001)$, but not among study sites (Table 1). There was a highly significant time $x$ site interaction $(p<0.0001)$. Mean salinity was significantly higher at LOB (35.9 ppt), MPI (35.3 ppt), and CLA (35.0 ppt), due to recurrent urban runoff events (Figure 2c). Conductivity was significantly different among sampling dates $(\mathrm{p}<0.0001)$, but not among study sites (Table 1$)$. There was a highly significant time $\mathrm{x}$ site interaction $(\mathrm{p}<0.0001)$. Conductivity was significantly lower at CLA (52.8 ms), MPI (53.4 ms), and LOB (54.1 ms) (Figure 2d). 
Table 1. Summary results of a two-way PERMANOVA test of environmental parameters

\begin{tabular}{|l|c|c|c|}
\hline Parameter* & Time & Site & Time x Site \\
\hline Temperature & $9.18(\mathrm{p}<0.0001)$ & $22.64(\mathrm{p}<0.0001)$ & $19.44(\mathrm{p}<0.0001)$ \\
\hline $\mathrm{pH}$ & $40.68(\mathrm{p}<0.0001)$ & $4.83(\mathrm{p}=0.0001)$ & $13.33(\mathrm{p}<0.0001)$ \\
\hline Salinity & $19.79(\mathrm{p}<0.0001)$ & $1.05(\mathrm{p}=0.3918)$ & $13.85(\mathrm{p}<0.0001)$ \\
\hline Conductivity & $18.25(\mathrm{p}<0.0001)$ & $1.09(\mathrm{p}=0.3677)$ & $8.79(\mathrm{p}<0.0001)$ \\
\hline Dissolved oxygen & $5.83(\mathrm{p}=0.0002)$ & $3.81(\mathrm{p}=0.0002)$ & $2.72(\mathrm{p}=0.0001)$ \\
\hline Turbidity & $3.66(\mathrm{p}=0.0028)$ & $36.42(\mathrm{p}<0.0001)$ & $11.50(\mathrm{p}<0.0001)$ \\
\hline FC & $0.52(\mathrm{p}=0.7915)$ & $49.26(\mathrm{p}<0.0001)$ & $20.45(\mathrm{p}<0.0001)$ \\
\hline ENT & $5.17(\mathrm{p}=0.0002)$ & $13.38(\mathrm{p}<0.0001)$ & $9.87(\mathrm{p}<0.0001)$ \\
\hline
\end{tabular}

*D.F.: Time $(6,161)$; Site $(9,158)$; Time x Site $(63,104)$

There was a highly significant difference in dissolved oxygen concentration among sampling dates $(\mathrm{p}=0.0002)$, among study sites $(\mathrm{p}=0.0002)$, and a significant time $\mathrm{x}$ site interaction $(\mathrm{p}=0.0001)$ (Table 1). Dissolved oxygen was also significantly higher in shallow inner bay sites (9.20-9.60 mg/L) (Figure 3a), in spite of receiving recurrent runoff impacts. The inner bay faced east trade winds which contributed to stronger mixing, which, in combination to incoming oxygen-rich tides, buffered low-oxygen, sewage-polluted runoff pulses. Sampling was always conducted during high tide, which contributed with oxygen-rich water. However, the observed significant temporal variation in dissolved oxygen concentration was associated to either, wind or runoff impacts. There was a highly significant difference in turbidity among sampling dates $(\mathrm{p}=0.0028)$, among study sites $(\mathrm{p}<0.0001)$, and a highly significant time $\mathrm{x}$ site interaction $(\mathrm{p}<0.0001)$ (Table 1$)$. Turbidity was significantly higher during major runoff pulse events (Figure 3b).
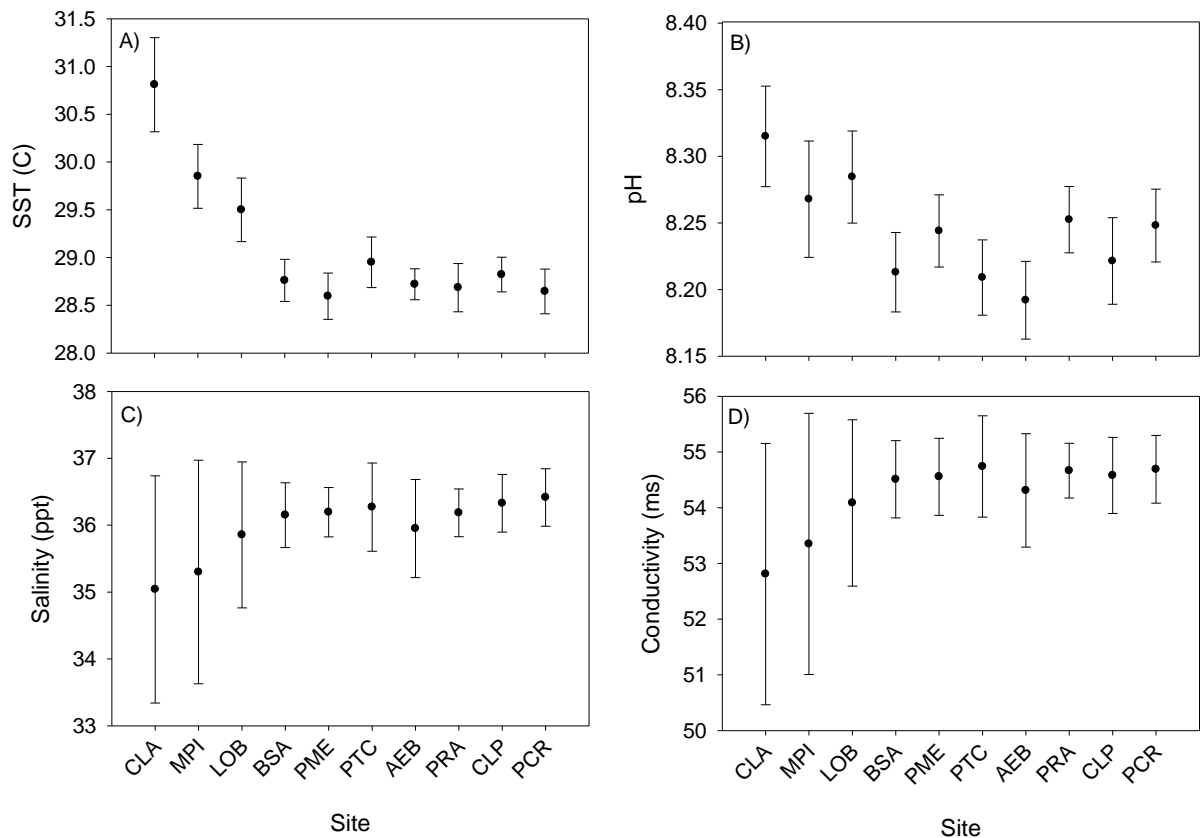

Figure 2. Environmental parameters across study sites: (A) Sea surface temperature $\left({ }^{\circ} \mathrm{C}\right)$; (B) $\mathrm{pH}$; (C) Salinity (ppt); and D) Conductivity (ms). Mean $\pm 95 \%$ confidence intervals 


\section{Macrothink}

FC concentration was significantly different among sites $(\mathrm{p}<0.0001)$, but not among sampling dates (Table 1). There was a significant time $x$ site interaction $(\mathrm{p}=0.0001)$. FC concentration was significantly higher in shallow inner bay sites LOB, with a mean value of $547 \mathrm{cfu} / 100$ $\mathrm{mL}$, followed by CLA (479 cfu/100 mL), and MPI (231 cfu/100 mL) (Figure 3c). FC concentrations reflected recurrent runoff pulse impacts at BSA (87 cfu/100 mL) and at PRA $(66.3 \mathrm{cfu} / 100 \mathrm{~mL})$. ENT concentrations were significantly different among sampling dates $(p=0.0002)$, and sites $(p<0.0001)$, with a significant time $x$ site interaction $(p<0.0001)$. ENT concentration was significantly higher at the urban coral reef system at BSA (877 cfu/100 $\mathrm{mL}$ ), followed by the shallow inner bay sites LOB (569 cfu/100 mL), CLA (205 cfu/100 mL), and MPI (80 cfu/100 mL) (Figure 3d). ENT concentrations reflected recurrent runoff impacts across CLPNR (6-88 cfu/100 mL).

Microbial indicator bacteria showed a variable relationship with other environmental factors. FC counts significantly increased $\left(r^{2}=0.6692, p=0.0038\right)$ with increasing SST (Figure 4a), but ENT counts did not (Figure 4b). Also, FC counts showed a significant increase $\left(r^{2}=0.5396\right.$, $\mathrm{p}=0.0155$ ) with declining salinity (Figure 4c), but ENT counts did not (Figure 4d). FC counts showed a significant increase $\left(\mathrm{r}^{2}=0.7860, \mathrm{p}=0.0006\right)$ with increasing turbidity (Figure $\left.4 \mathrm{e}\right)$, but ENT counts did not (Figure 4f). Observed patterns showed that FC concentration in coastal waters quickly responded to recurrent runoff pulses, particularly during higher SST in late summer months, but ENT was more associated to raw sewage spills which did not always followed urban runoff dynamics.

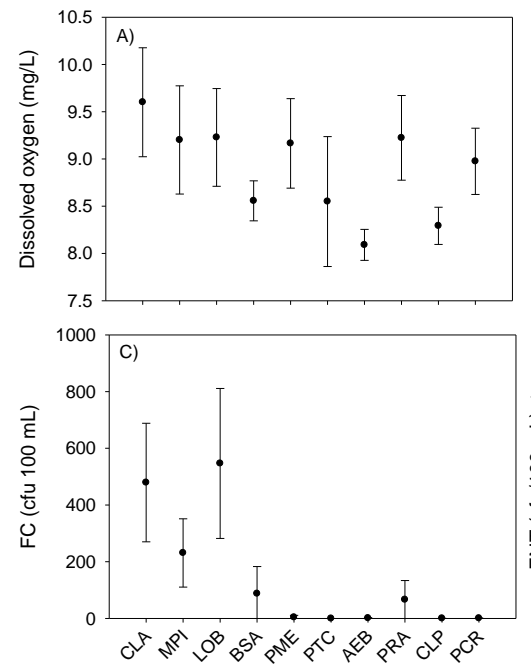

Site

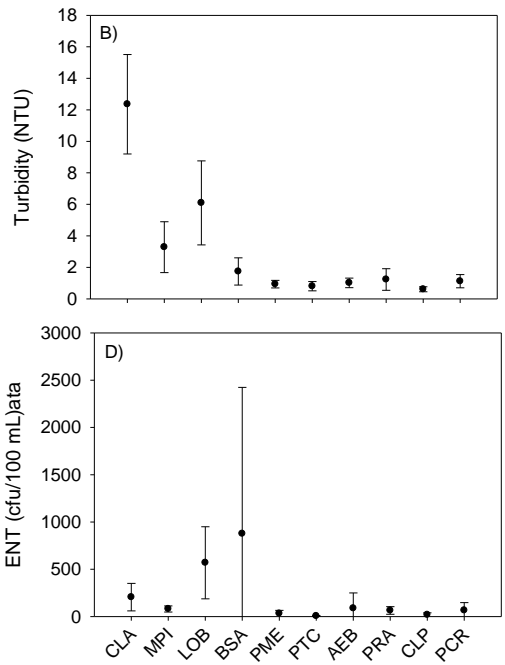

Site

Figure 3. Environmental parameters across study sites: (A) Dissolved oxygen concentration (mg/L); (B) Turbidity (NTU); (C) FC (cfu/100 mL); and D) ENT (cfu/100 mL). Mean $\pm 95 \%$ confidence intervals 

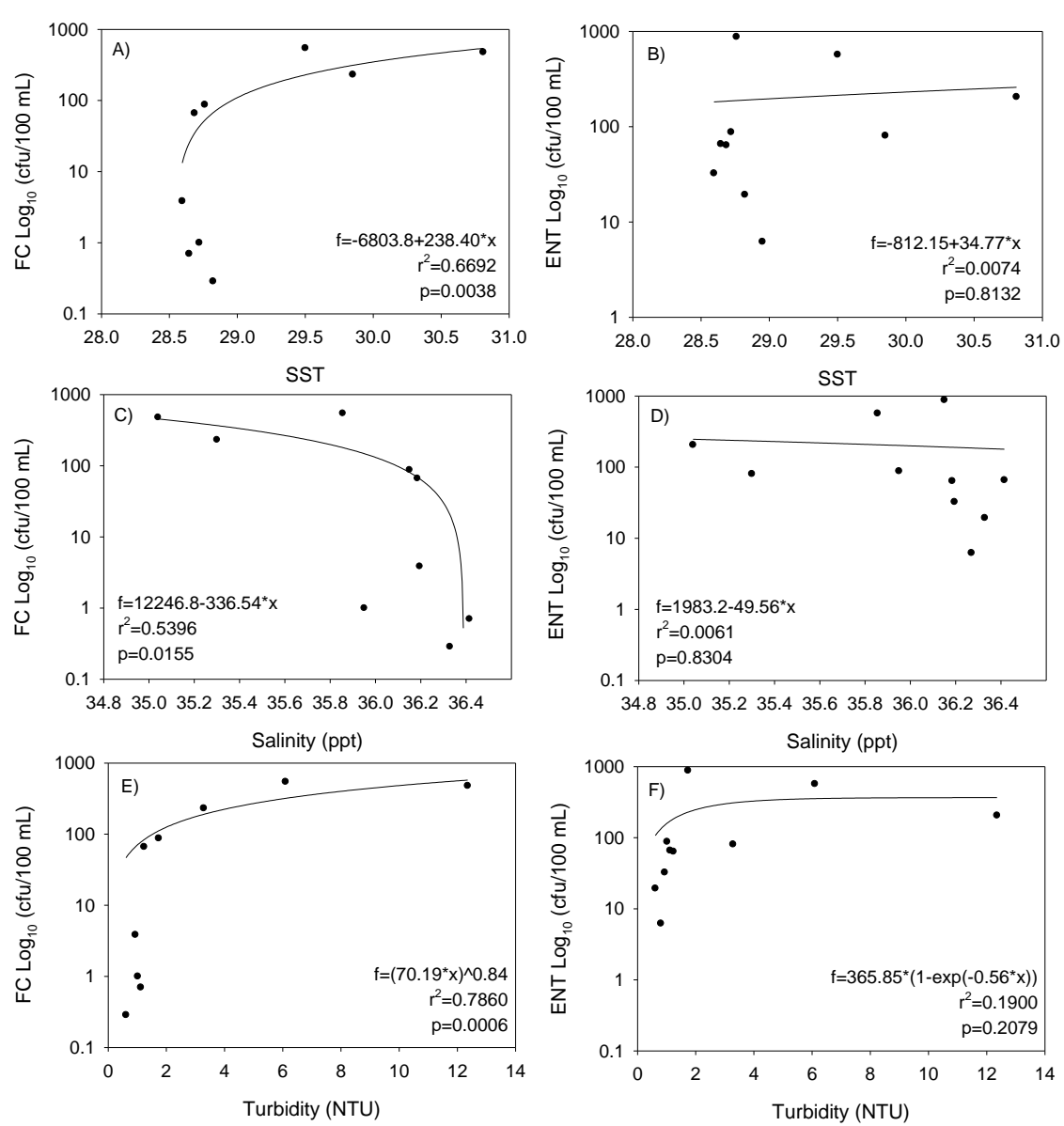

Figure 4. Microbial indicator regression analyses: (A) FC counts vs. SST; (B) ENT counts vs. SST; (C) FC counts vs. salinity; (D) ENT counts vs. salinity; (E) FC counts vs. turbidity; (F) ENT counts vs. turbidity

\subsection{Spatio-temporal Variation in the Water Quality Stress Gradient}

Principal coordinates ordination (PCO) analysis showed four different temporal clusters, with the months of May, June and November being largely explained by urban runoff pulses reflected by changes in salinity, conductivity, $\mathrm{pH}$, turbidity, and dissolved oxygen concentration (Figure 5). A second individual cluster of July can also be explained by changes in salinity and conductivity. A third cluster composed of August and October, as well as a fourth individual cluster of September were explained by changes in FC and ENT counts, and by higher SST. This solution explained $71.3 \%$ of the observed temporal variation.

PCO analysis also showed six different spatial clusters, with PTC, AEB and CLP being largely explained by runoff pulses reflected by changes in salinity and conductivity (Figure 6). A second cluster was composed of PCR, PME, PRA, and was explained by variation in $\mathrm{pH}$, SST, and dissolved oxygen concentration. An individual cluster constituted by BSA was explained by variation in ENT. Three separate individual clusters, separately constituted by LOB, MPI, and CLA were explained by variation in FC. This solution explained $86.6 \%$ of the observed spatial variation, suggesting an evident environmental stress spatial gradient.

A multivariate correlation analysis showed that there was a strongly significant positive 
correlation between ENT and water turbidity (Rho=0.613, $p=0.0008$ ), suggesting the relationship between sewage and runoff pulses. But no correlation was found between FC and water turbidity $(\mathrm{Rho}=0.135, p=0.2500)$. FC growth showed significant interference by background bacteria under high turbidity when using standard methods, which could account for the lack of correlation. Thus, high data variability could probably explain the observed lack of spatial resolution and correlation, and the highly variable runoff pulse dynamics.

\subsection{Coral Species Richness, Colony Abundance and Percent Cover of Benthic Components across an Environmental Stress Gradient}

Most coral reef benthic community parameters showed significant differences among sites (Table 2). Total coral (scleractinian, hydrocoral, octocoral) species richness was significantly higher $(\mathrm{p}=0.004)$ at PTC (9.2 species/transect), followed by PRA (7.5 species/transect) (Figure 7a). Total coral species richness was significantly lower at BSA (3.7 species/transect). This reef was the closest to polluted urban areas. Hard coral (scleractinian, hydrocoral) species richness was significantly higher $(\mathrm{P}=0.0117)$ at PTC and AEB (6.5 species/transect), and significantly lower at BSA (3.7 species/transect) (Figure 7a). Octocoral species richness (data not shown) showed a significant $(\mathrm{p}=0.0002)$ spatial gradient, with higher abundance at sites with stronger surface currents and ocean circulation (e.g., PTC, PME, PRA).

Total coral colony abundance was significantly higher $(\mathrm{p}=0.0002)$ at PTC (25 colonies/transect), followed by PRA (23 colonies/transect) (Figure 7b). Total coral colony abundance resulted lower at CLP (10 colonies/transect), followed by BSA (14 colonies/transect). Hard coral colony abundance was significantly higher $(\mathrm{p}=0.0034)$ at PTC (17 colonies/transect), and significantly lower at CLP (7 colonies/transect). Octocoral colony abundance were also significantly higher $(\mathrm{p}=0.0106)$ at strong circulation sites. Percent total living coral cover was significantly higher $(\mathrm{p}<0.0001)$ at PME $(40 \%)$, closely followed by PRA (39\%), and significantly lower at CLP (17\%), and at BSA (22\%) (Figure 7c).

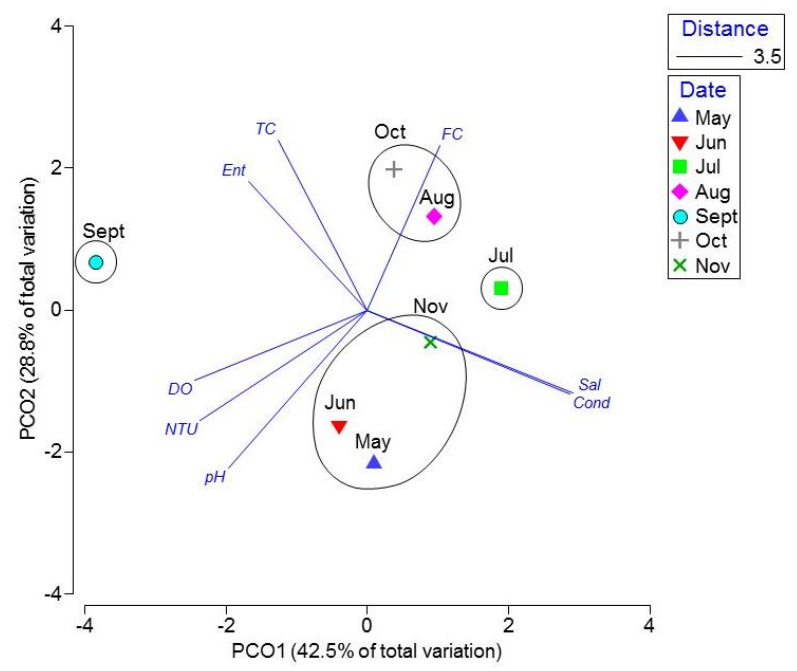

Figure 5. Principal coordinates ordination plot (PCO) based on temporal variation in environmental parameters. Clusters based on 3.5 Euclidean distance. This model explains

$71.3 \%$ of the observed temporal variation 

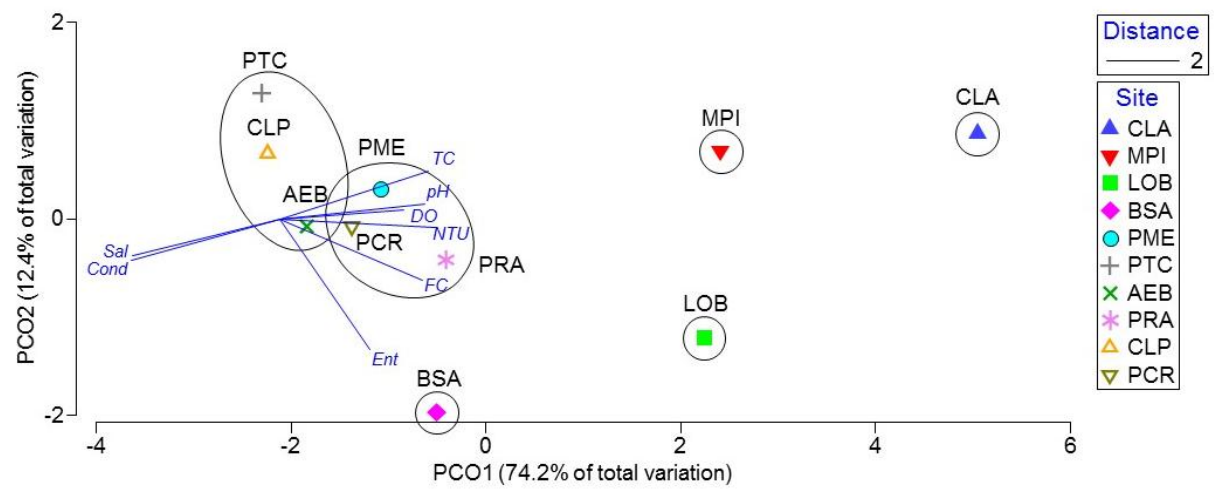

Figure 6. Principal coordinates ordination plot (PCO) based on spatial variation in environmental parameters. Clusters based on 2.0 Euclidean distance. This model explains $86.6 \%$ of the observed spatial variation

Table 2. Summary results of a one-way PERMANOVA analysis of coral reef benthic parameters among sites (d.f. $=6,32)$. NS $=$ Not significant $(p>0.0500)$

\begin{tabular}{|l|c|c|}
\hline Parameter & Pseudo F & P value \\
\hline Species richness (total) & 5.90 & 0.0004 \\
\hline Species richness (hard) & 3.35 & 0.0117 \\
\hline Species richness (octocorals) & 9.33 & 0.0002 \\
\hline Colony abundance (total) & 8.96 & 0.0002 \\
\hline Colony abundance (hard) & 4.12 & 0.0034 \\
\hline Colony abundance (octocorals) & 3.38 & 0.0106 \\
\hline \% Total coral & 11.28 & $<0.0001$ \\
\hline \% Scleractinian & 28.27 & $<0.0001$ \\
\hline \% Hydrocoral & 8.01 & 0.0002 \\
\hline \% Octocoral & 6.97 & 0.0004 \\
\hline \% Acropora palmata & 0.65 & $0.7284(\mathrm{NS})$ \\
\hline \% Old coral mortality & 4.23 & 0.0027 \\
\hline \% Recent coral mortality & 3.13 & 0.0189 \\
\hline H'c (total) & 7.33 & 0.0003 \\
\hline H'c (hard) & 3.98 & 0.0057 \\
\hline H'c (octocorals) & 3.65 & 0.0087 \\
\hline J'c (total) & 5.26 & 0.0018 \\
\hline J'c (hard) & 3.21 & 0.0155 \\
\hline J'c (octocorals) & 3.75 & 0.0077 \\
\hline \% Sponges & 5.11 & 0.0014 \\
\hline \% Zoanthids & 2.69 & 0.0326 \\
\hline \% Macroalgae & 6.77 & 0.0002 \\
\hline \% Turf & 17.27 & $<0.0001$ \\
\hline \% Halimeda spp. & 9.70 & $<0.0001$ \\
\hline \% CCA & 46.40 & $<0.0001$ \\
\hline \% Cyanobacteria & 1.23 & $0.3173(\mathrm{NS})$ \\
\hline \% Sand, pavement, rubble & 22.20 & $<0.0001$ \\
\hline
\end{tabular}


Scleractinian coral percent cover was significantly higher $(\mathrm{p}<0.0001)$ at PTC, and AEB, with significantly lower values at AEB, CLP, and PME (Figure 7d). Hydrocoral percent cover was significantly higher $(\mathrm{p}=0.0002)$ at AEB and CLP, with significantly lower values at PCR and BSA. Octocoral percent cover was significantly higher $(\mathrm{p}=0.0004)$ at PRA, with significantly lower values at BSA. Elkhorn coral, Acropora palmata, distribution was not significantly different among sites.
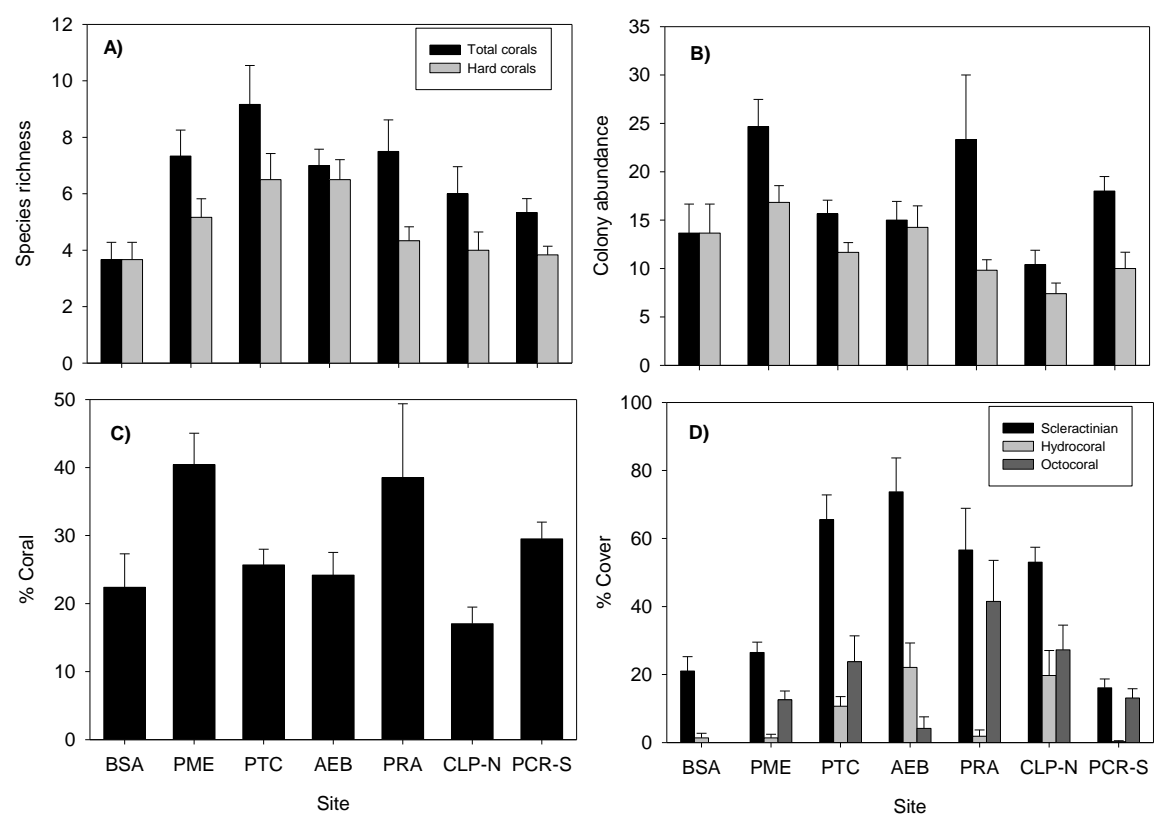

Figure 7. Coral reef indicator parameters: (A) Species richness (total and hard corals); (B) Colony abundance (total and hard corals); (C) Percent living coral cover (total corals); and (D) Percent living coral cover (Scleractinians, hydrocorals, octocorals). Mean $\pm 95 \%$ confidence intervals

Total coral species diversity index $\left(\mathrm{H}^{\prime} \mathrm{c}\right)$ was significantly higher $(\mathrm{p}=0.0003)$ at PTC $(2.0230)$, and significantly lower at BSA (0.8937) and PCR (1.3202) (Figure 8a). Hard coral H'c was significantly higher $(\mathrm{p}=0.0057)$ at AEB (1.7101) and at PTC (1.6969), and lower at BSA (0.8937). Octocoral H'c was significantly higher $(\mathrm{p}=0.0087)$ at strong circulation sites. Total coral species evenness (J'c) was significantly higher $(\mathrm{p}=0.0018)$ at PTC (0.9377), AEB (0.9294), CLP (0.9126), and PRA (0.8863) (Figure 8b). Total coral J'c was significantly lower at BSA (0.8000). Hard coral J'c was significantly higher $(\mathrm{p}=0.0155)$ at PTC $(0.9281)$ and at AEB (0.9252), and significantly lower at BSA (0.7145). Octocoral J'c was also significantly higher $(\mathrm{p}=0.0077)$ at strong circulation sites. 

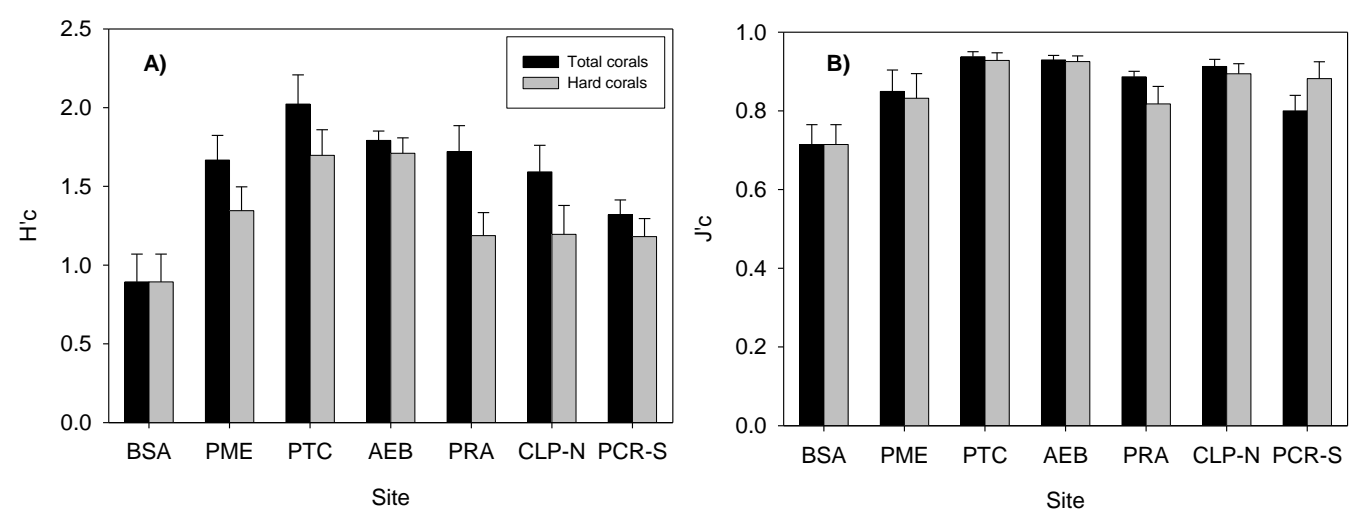

Figure 8. Coral species diversity: (A) Species diversity index (H'c); and (B) Evenness (J'c). Mean $\pm 95 \%$ confidence intervals
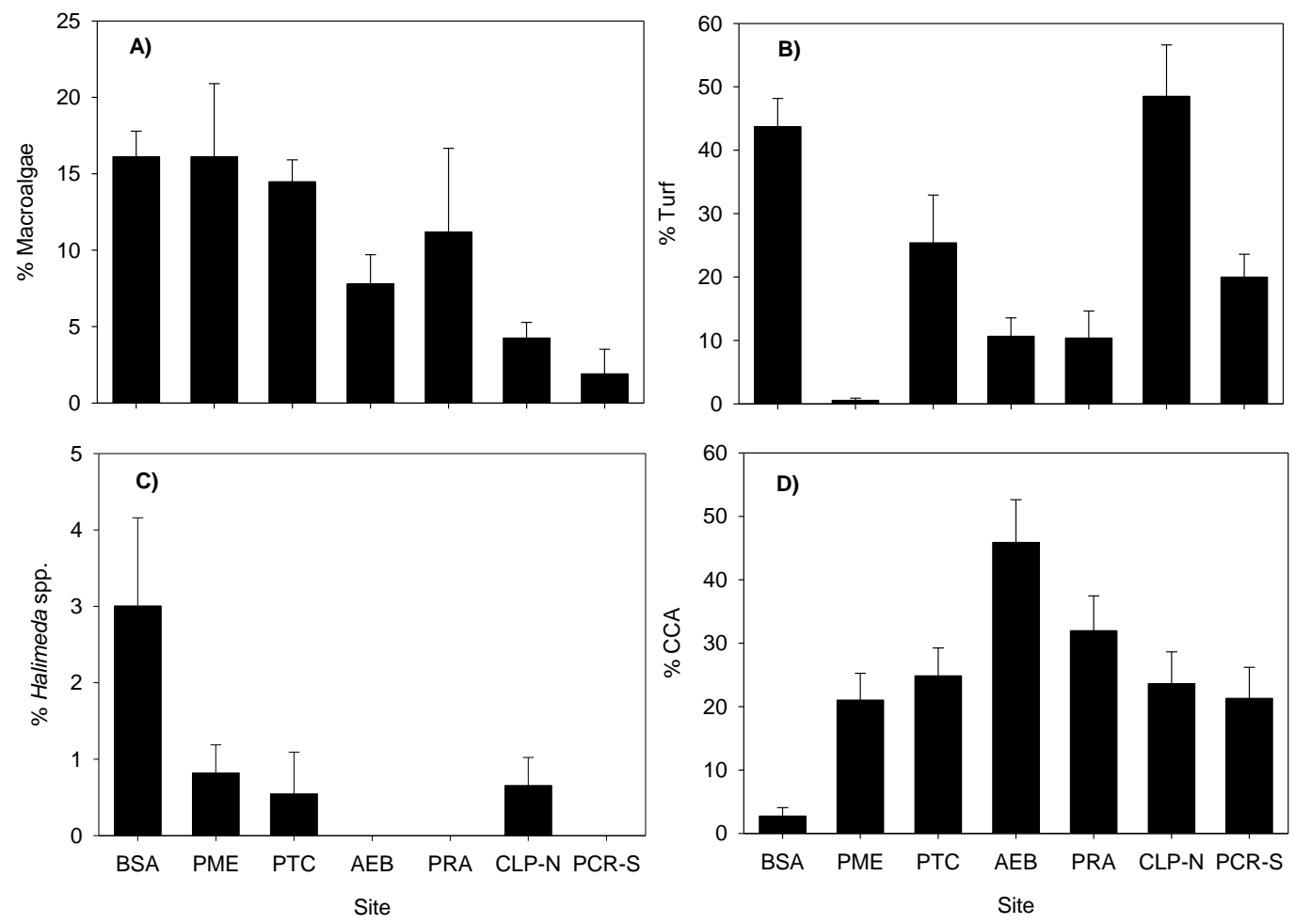

Figure 9. Coral reef algal communities: (A) Percent macroalgal cover; (B) Percent algal turf cover; (C) Percent Halimeda spp.; and (D) Percent crustose coralline algae (CCA). Mean $\pm 95 \%$ confidence intervals

Macroalgal distribution showed unequivocal influences of the non-point source pollution gradient, with significantly higher $(\mathrm{p}=0.0002)$ percent cover at the non-point source polluted BSA (16\%), followed by nearby downstream reefs at PTC (14\%), and PRA (11\%) (Figure 9a). Percent algal turf cover was significantly higher $(\mathrm{p}<0.0001)$ at CLP $(49 \%)$ and BSA $(43 \%)$, with the lowest value at PME $(<1 \%)$ (Figure $9 \mathrm{~b}$ ). Halimeda spp. cover was significantly higher $(\mathrm{p}<0.0001)$ at BSA (Figure 9c). CCA was significantly higher $(\mathrm{p}<0.0001)$ at AEB (Figure 9d). AEB supports the highest density of Long-spine urchins (Diadema antillarum), thus the highest grazing intensity on other algal functional groups. 

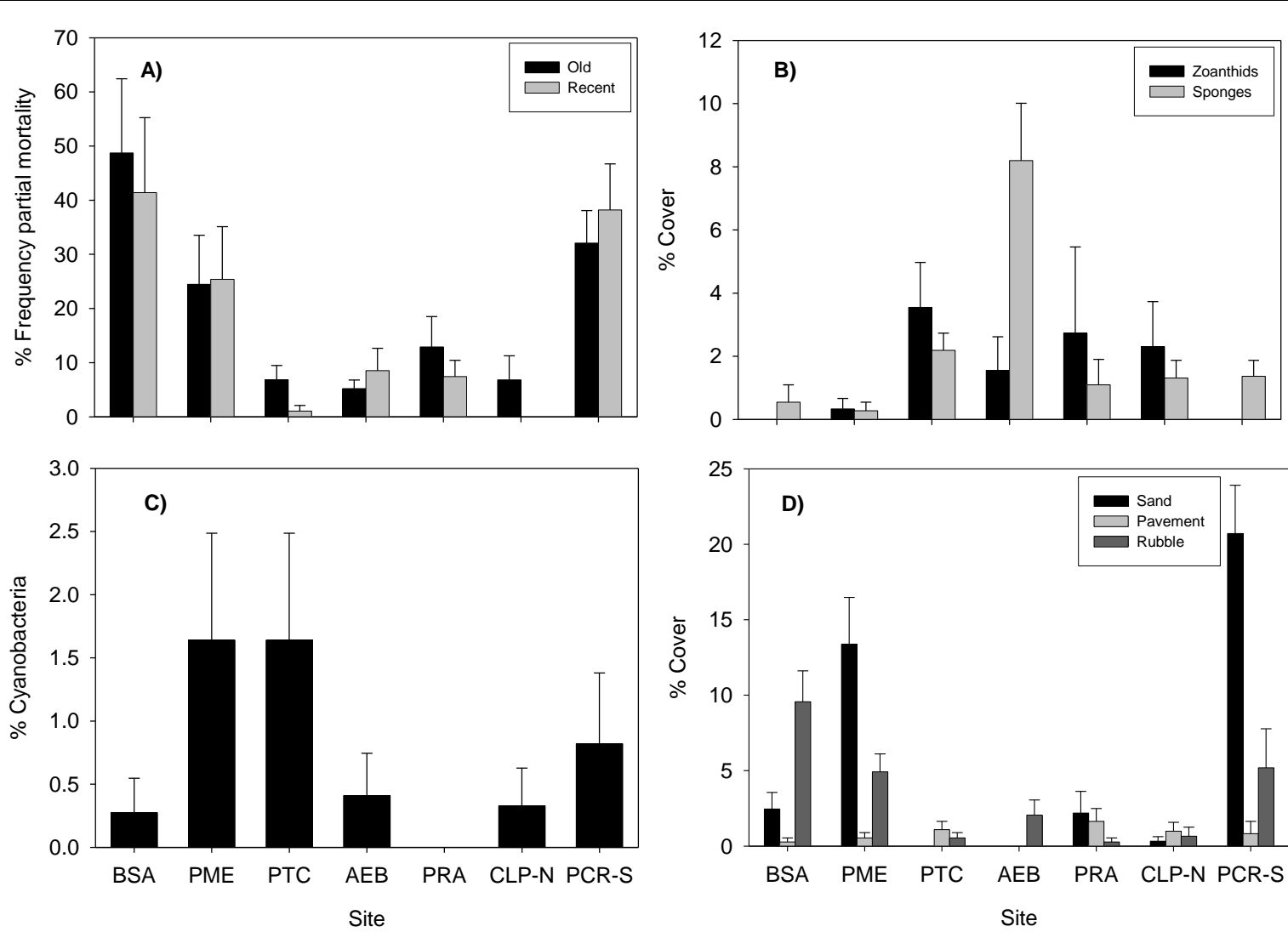

Figure 10. Other coral reef benthic community indicators: (A) Frequency partial coral colony mortality (recent, old); (B) Percent sponge and zoanthid cover; (C) Percent cyanobacterial cover; and (D) Percent cover of open substrates (sand, pavement, rubble).

Mean $\pm 95 \%$ confidence intervals

3.4 Coral Mortality and Other Non-Reef Building Components: Impacts by Non-Point Source Pollution and Sediment Bedload Revealed

Percent frequency of old mortality of coral colonies was significantly higher $(\mathrm{p}=0.0027)$ at BSA (49\%), followed by PCR (32\%) (Figure 10a). Lowest values were documented at AEB (5\%), followed by PTC, and CLP, with 7\%, respectively. This pattern suggests two long-term trends of reef degradation. The first one points out at the long-term decline of BSA, which is the reef located closest to Dewey downtown area. The second pattern implies significant long-term decline associated to sediment bedload or horizontal transport at PCR.

Percent frequency of recent mortality of coral colonies was also significantly higher $(\mathrm{p}=0.0189)$ at BSA $(41 \%)$, followed by PCR $(38 \%)$ (Figure $10 \mathrm{a})$. No recent mortality was observed at CLP, and only $1 \%$ recent mortality was detected at PTC. This suggests that mortality was highly active across the urban reef and across the reef impacted by sediment bedload. Further, $90 \%$ of the living hard corals at BSA, and $70 \%$ of the living hard corals at PCR showed at least some degree of partial colony mortality. This suggests that stressful conditions were significant and that both, impacts by non-point source pollution, as well as sediment bedload, can have similar adverse long-term effects on shallow-water coral assemblages. Coral mortality is nearly absent at coral reefs subjected to strong water 


\section{Mll Macrothink

circulation, which lacked sediment deposition.

Percent zoanthid cover was significantly higher $(\mathrm{p}=0.0326)$ at strong circulation sites (Figure 10b). AEB showed a significantly higher $(\mathrm{p}=0.0014)$ percent sponge cover (Figure 10b). Cyanobacterial cover was non-significantly higher at PME and PTC (Figure 10c). Sandy bottoms were significantly $(\mathrm{p}<0.0001)$ more abundant at PCR, open pavement at PRA, and rubble at BSA (Figure 10d).

\subsection{Multivariate Patterns in Benthic Community Structure: Evidence of an Environmental Stress Gradient}

Benthic community structure showed highly significant $(\mathrm{p}=0.0002)$ spatial variation among study sites (Table 3). All paired site combinations were significantly different, excepting the combinations of PRA-CLP, and PTC-CLP, which were not. PCO analysis demonstrated a highly significant influence of environmental variables structuring coral reef benthic communities (Figure 11). Three clustering patterns were evidenced which reflected impacts by a water quality stress gradient. The first cluster was an individual site, BSA, which was adjacent to urban influences. This cluster was tightly associated to a second small cluster composed by PME and PCR. PME was geographically adjacent to BSA, and both were mostly influenced by variation in FC and dissolved oxygen concentrations, and by variation in $\mathrm{pH}$ and conductivity, both associated to recurrent runoff pulses. Variation at PCR, which was the most distant reef from urban influences, were largely explained by water turbidity associated to sediment-loaded runoff pulses and bedload impacts, and by variation in ENT concentrations associated to sporadic remote sewage pulses. The third cluster was composed by the remaining four coral reefs, AEB, PTC, PRA, and CLP. These stronger water circulation sites were better explained by differences in water temperature.

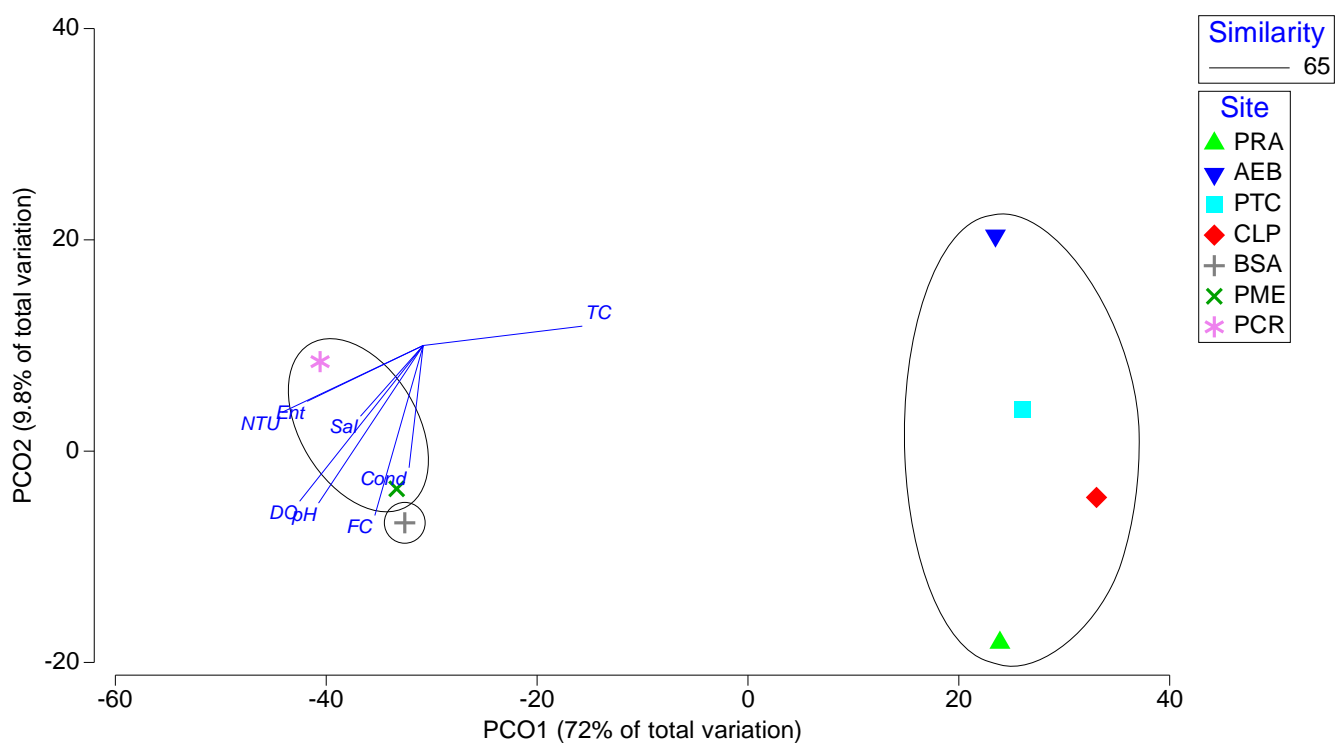

Figure 11. Principal coordinates ordination plot (PCO) based on spatial variation in coral reef benthic community structure as a function of environmental variables. Clusters based on $65 \%$ community similarity cutoff level. This model explains $81.8 \%$ of the observed spatial variation 


\section{Ml Macrothink}

Hard coral (Scleractinian, hydrocoral) species accumulation plot also suggests a strong environmental stress gradient affecting species spatial distribution, with fewer species present across the urban coral reef at BSA and across PCR, the most affected reef by sediment bedload (Figure 12). Hard corals were most abundant across strong water circulation sites. A shade plot also showed the environmental stress gradient effect, suggesting coral dominance by disturbance-tolerant coral Porites astreoides at BSA, PCR, and PME (Figure 13). Disturbance-tolerant Brain coral, Pseudodiploria strigosa, was also common at PCR and PME. Hydrocorals and octocorals were more common at shallow high circulation sites. Macroalgae, turf and open substrates were more common across sites impacted by runoff impacts and sediment bedload. CCA was more abundant at strong circulation sites AEB, PRA, PTC, and CLP, particularly in areas exposed to strong herbivory by the Long-spine urchin, Diadema antillarum.

Benthic categories across surveyed reefs were often dominated by non-reef building components (Table 4). Porites porites, rubble and macroalgae dominated benthic assemblages at BSA urban reef. CCA, algal turf, sponges and Porites spp. were the dominant components of strong circulation sites. Sand, rubble, and $P$. porites were the dominant components at PCR reef subjected to strong sediment bedload impacts.

Table 3. Results of a one-way PERMANOVA test of benthic community structure among study sites $($ d.f. $=6,32)$. NS $=$ Not significant $(p>0.0500)$.

\begin{tabular}{|l|l|l|}
\hline Factors & Pseudo-F & P value \\
\hline $\begin{array}{l}\text { Global test } \\
\text { Site }\end{array}$ & 9.84 & 0.0002 \\
\hline Pairwise test - Site & & \\
PRA vs. AEB & 1.44 & 0.0442 \\
PRA vs. PTC & 1.44 & 0.0242 \\
PRA vs. CLP & 1.30 & 0.1192 (NS) \\
PRA vs. PCR & 3.33 & 0.0022 \\
PRA vs. BSA & 3.38 & 0.0019 \\
PRA vs. PME & 3.10 & 0.0015 \\
\hline AEB vs. PTC & 1.37 & 0.0384 \\
AEB vs. CLP & 1.90 & 0.0148 \\
AEB vs. PCR & 3.56 & 0.0043 \\
AEB vs. BSA & 4.10 & 0.0053 \\
AEB vs. PME & 3.96 & 0.0049 \\
\hline PTC vs. CLP & 1.32 & $0.1146(\mathrm{NS})$ \\
PTC vs. PCR & 4.22 & 0.0021 \\
PTC vs. BSA & 4.30 & 0.0022 \\
PTC vs. PME & 4.18 & 0.0016 \\
\hline CLP vs. PCR & 4.24 & 0.0028 \\
CLP vs. BSA & 4.60 & 0.0022 \\
CLP vs. PME & 4.56 & 0.0020 \\
\hline PCR vs. BSA & 2.24 & 0.0030 \\
PCR vs. PME & 2.06 & 0.0038 \\
\hline BSA vs. PME & 2.49 & 0.0021 \\
\hline
\end{tabular}




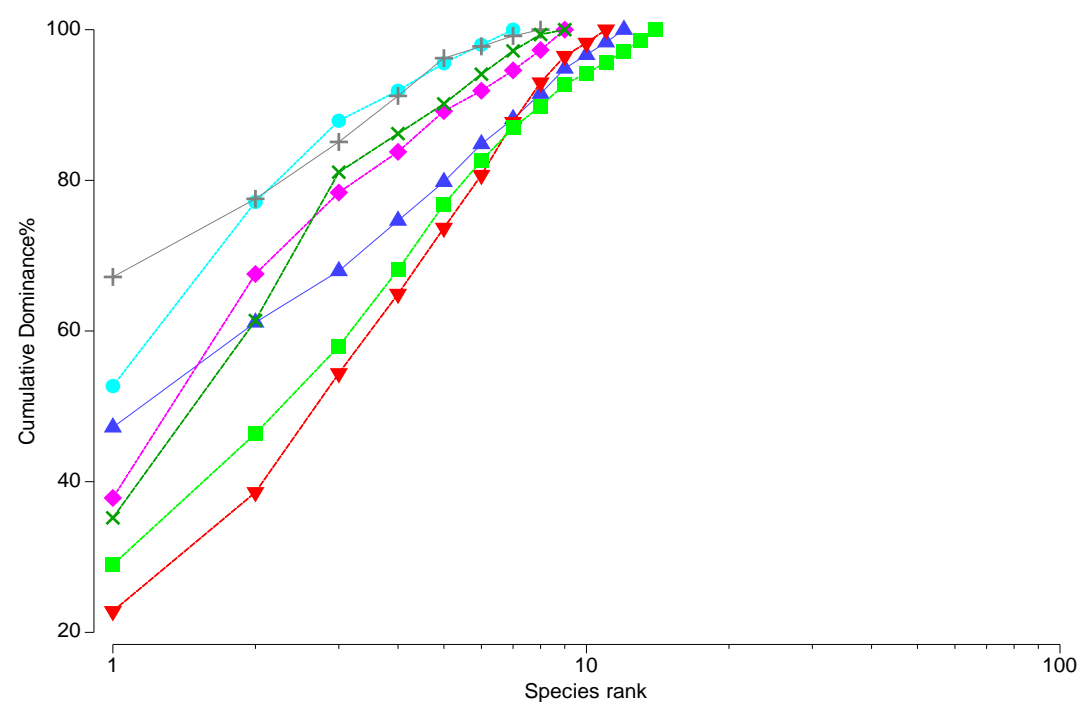

Figure 12. Hard coral (Scleractinian, hydrocoral) species accumulation plot per site across an environmental stress gradient

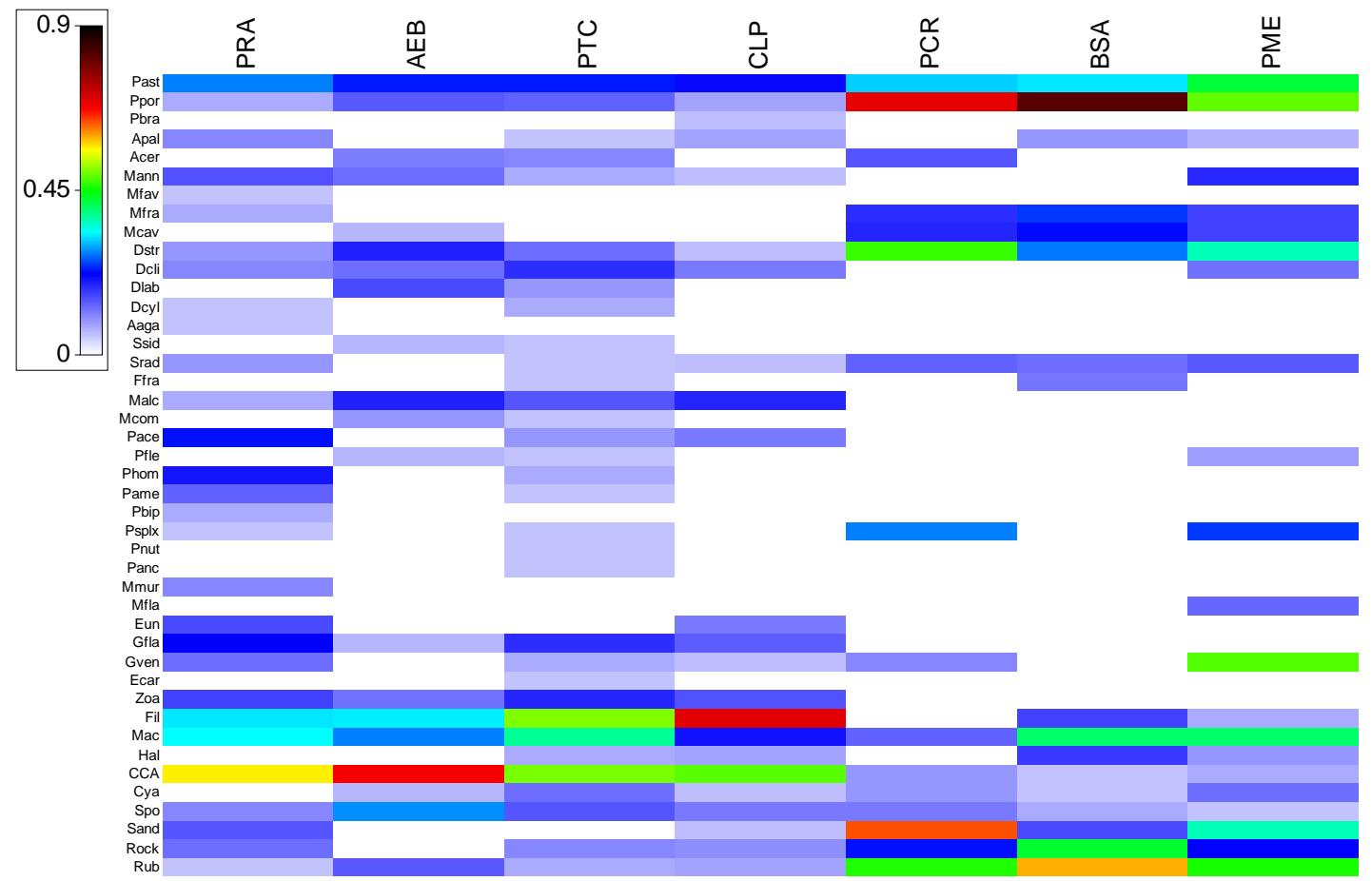

Figure 13. Shade plot showing relative dominance by different benthic categories across an environmental stress gradient. 


\section{Macrothink}

Environmental Management and Sustainable Development

ISSN 2164-7682

2017, Vol. 6, No. 2

Table 4. Cumulative percent of the three most dominant benthic components of each site based on the SIMPER routine

\begin{tabular}{|c|l|c|}
\hline Site & \multicolumn{1}{|c|}{ Benthic components } & Cumulative \% \\
\hline BSA & P. porites, rubble, macroalgae & 66.66 \\
\hline PME & G. ventalina, rubble, P. porites & 40.31 \\
\hline PTC & CCA, algal turf, macroalgae & 52.89 \\
\hline AEB & CCA, algal turf, sponges & 54.30 \\
\hline PRA & CCA, macroalgae, P. astreoides & 64.94 \\
\hline CLP & Algal turf, CCA, P. astreoides & 68.70 \\
\hline PCR & Sand, rubble, P. porites & 71.15 \\
\hline
\end{tabular}

Algal turf explained $32 \%$ of the benthic community differences among sites, P. porites explained 23\%, CCA 18\%, Gorgonia ventalina, sponge, and sandy bottoms 9\%, respectively, of the variation (Table 5). BSA benthic community was significantly different from the rest largely due to dominance of surviving patches of $P$. porites, while benthic communities at PME were significantly different due to dominance of open substrates covered with high CCA cover in most other sites that sustain large populations of D. antillarum. Algal turfs explained most differences between PTC and other sites. Sponges, algal turf and CCA explained differences between PRA and other sites. Algal turf and P. porites explained differences at PRA, and algal turfs at CLP. Sand was the most important factor explaining differences at PCR.

Table 5. Major components explaining structural differences in benthic community structure among sites based on the SIMPER routine.

\begin{tabular}{|l|l|l|l|l|l|l|}
\hline Sites & BSA & PME & PTC & AEB & PRA & CLP \\
\hline PME & G. ventalina & & & & & \\
\hline PTC & P. porites & CCA & & & & \\
\hline AEB & P. porites & CCA & Turf & Sponge & & \\
\hline PRA & P. porites & CCA & Turf & Sponge & & \\
\hline CLP & P. porites & Turf & Turf & Turf & Turf & \\
\hline PCR & Sand & G. ventalina & Sand & CCA & P. porites & Turf \\
\hline
\end{tabular}

\subsection{Linking Environmental Variables to Benthic Assemblages}

RELATE (Spearman Rank) correlation routine showed a highly significant correlation between benthic community structure and the combination of water turbidity, and the concentration of FC and ENT (Rho=0.668, $\mathrm{p}=0.0020)$. LINKTREE regression analysis showed an initial (A) clustering pattern of benthic assemblages resulting from variation in dissolved oxygen concentration $(\mathrm{R}=0.56, \mathrm{~B}=87 \%)$ (Figure 14). There was a second (C) clustering pattern resulting from variation in the combination of $\mathrm{pH}$ and dissolved oxygen $(\mathrm{R}=1.00, \mathrm{~B}=95 \%)$. The model suggested other alternatives but with lower significance $(\mathrm{B}=29-42 \%)$. 


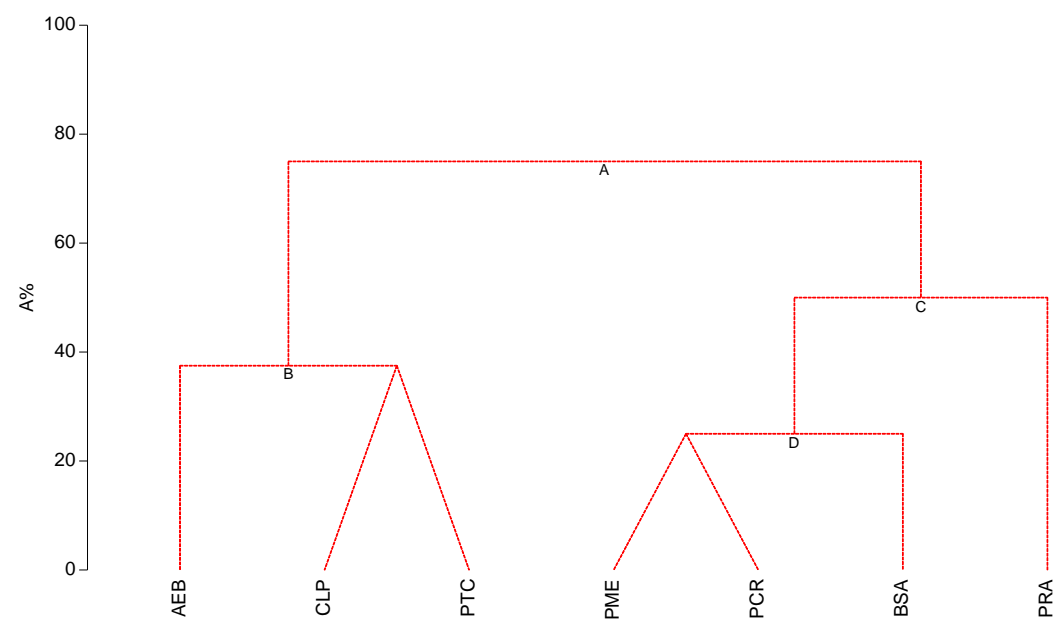

$\mathrm{A}: \mathrm{R}=0.56 ; \mathrm{B} \%=87 ; \mathrm{DO}<-0.311(>-0.296)$

B: $\mathrm{R}=1.00 ; \mathrm{B} \%=42 ; \mathrm{Sal}<-1.78(>0.383)$ or $\mathrm{Cond}<-1.87(>0.00253)$ or Ent $>0.313(<-0.676)$ or $\mathrm{TC}<-0.163(>0.692)$ or $\mathrm{pH}<-1.47(>-0.729)$ or NTU>-0.0728(<-0.732) or $\mathrm{DO}<-1.4(>-0.915)$ or $\mathrm{FC}>-0.521(<-0.755)$

$\mathrm{C}: \mathrm{R}=1.00 ; \mathrm{B} \%=95 ; \mathrm{pH}<0.974(>1.17)$ or $\mathrm{DO}<1.07(>1.2)$

$\mathrm{D}: \mathrm{R}=1.00 ; \mathrm{B} \%=29$; Ent $<0.123(>1.85)$ or $\mathrm{FC}<-0.0523(>1.48)$ or $\mathrm{NTU}<0.231(>1.75)$ or $\mathrm{pH}>0.799(<-0.554)$ or $\mathrm{TC}<-0.796(>0.175)$ or $\mathrm{DO}>0.655(<-0.296)$ or $\mathrm{Cond}>-0.162(<-0.476)$ or $\mathrm{Sal}>-0.122(<-0.426)$

Figure 14. LINKTREE regression analysis of environmental variables to explain spatial patterns in benthic community structure

DISTLM marginal test analysis showed that ENT ( $\mathrm{p}=0.0642$; proportion $=0.4842$ ) and turbidity $(\mathrm{p}=0.0694$; proportion $=0.4821$ ) had only a marginally significant effect on explaining about half of the observed spatial variation in benthic community structure (Table 6). But sequential tests showed that the combination of changes in salinity, dissolved oxygen concentration, and ENT concentration explained $75 \%$ of the observed spatial variation in benthic community structure $(\mathrm{p}=0.0400$; proportion $=0.7461)$. $\mathrm{dbRDA}$ analysis showed that the observed gradient of coral reef benthic community structure conditions was significantly influenced by combined environmental variables. Particularly, variation at BSA was explained by FC, ENT, and turbidity (Figure 15). Variation at PCR was explained by dissolved oxygen concentration, salinity, and $\mathrm{pH}$.

Table 6. Summary of the DISTLM procedure examining the correlative relationships between benthic community structure and the environmental variables

Marginal tests

\begin{tabular}{|l|l|l|l|l|}
\hline Variable & SS (trace) & Pseudo F & $\mathrm{p}$ & Proportion \\
\hline ENT & 0.2452 & 4.69 & 0.0642 & 0.4842 \\
\hline Turbidity & 0.2441 & 4.65 & 0.0694 & 0.4821 \\
\hline FC & 0.0783 & 0.91 & 0.3519 & 0.1546 \\
\hline SST & 0.0702 & 0.81 & 0.4254 & 0.1387 \\
\hline Dissolved oxygen & 0.0351 & 0.37 & 0.5911 & 0.0693 \\
\hline pH & 0.0240 & 0.25 & 0.6568 & 0.0475 \\
\hline Salinity & 0.0234 & 0.24 & 0.6826 & 0.0462 \\
\hline Conductivity & 0.0015 & 0.01 & 0.9945 & 0.0029 \\
\hline
\end{tabular}


Sequential tests

\begin{tabular}{|l|l|l|l|l|l|l|}
\hline Variable & R2 & SS (trace) & Pseudo F & p & Proportion & Cumulative \\
\hline + Salinity & 0.0462 & 0.0234 & 0.24 & 0.6862 & 0.0462 & 0.0462 \\
\hline + Dissolved oxygen & 0.0892 & 0.0218 & 0.19 & 0.7738 & 0.04302 & 0.0892 \\
\hline + ENT & 0.7461 & 0.3326 & 7.76 & 0.0400 & 0.6569 & 0.7461 \\
\hline + FC & 0.8562 & 0.0557 & 1.53 & 0.3317 & 0.1101 & 0.8562 \\
\hline + NTU & 0.8944 & 0.0194 & 0.36 & 0.6864 & 0.0383 & 0.8944 \\
\hline
\end{tabular}

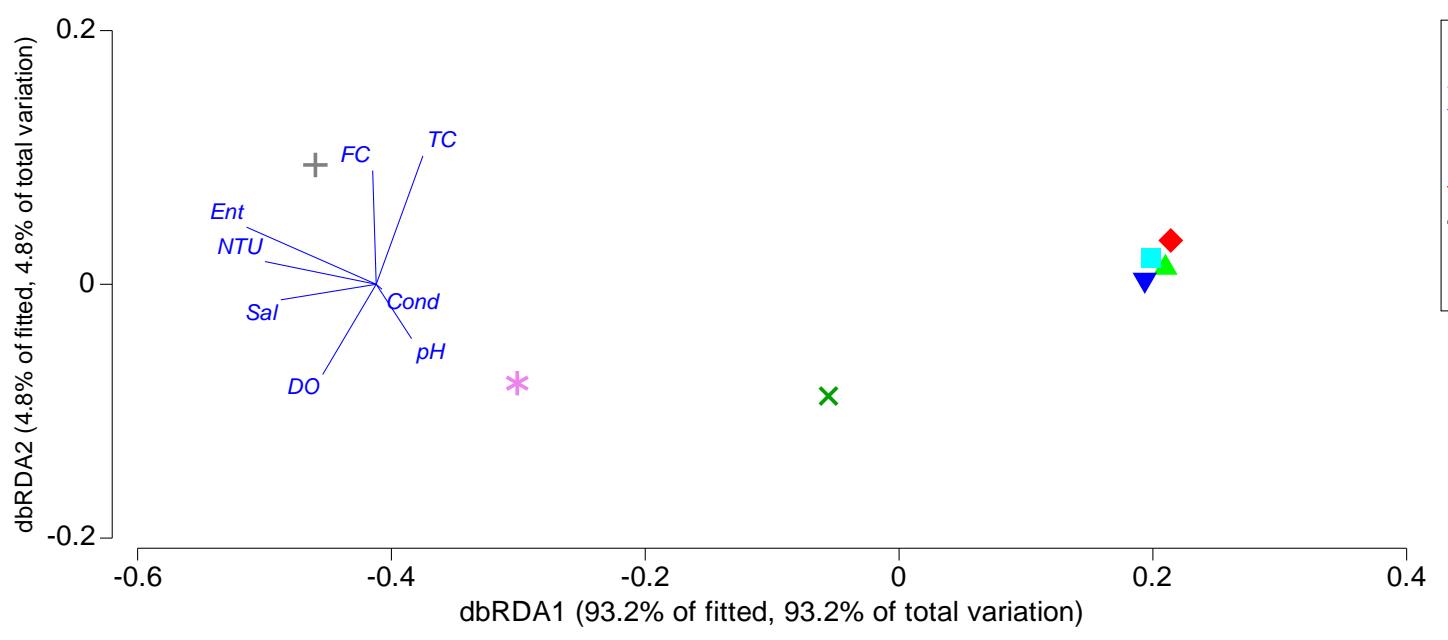

Figure 15. dbRDA plot derived from the biological and environmental data

\section{Discussion}

4.1 Cascading Effects of Urban Runoff and Eutrophication in a Climate of Change: Microbiological Quality Decline and Trouble for Corals

Observed levels of fecal contamination in the coastal waters of Culebra Island responded to nutrient-loaded, sewage-polluted, turbid urban runoff pulses, and can represent a significant threat to coral reef ecosystems and public health. There was a gradient of microbial indicator concentrations, with increasing mean values in waters adjacent to known urban pollution sources, and corresponding to shallow localities with higher SST and turbidity, and lower salinity, and conductivity. Lack of adequate sewage treatment facilities in Culebra Island have resulted in the proliferation of poorly designed and constructed septic tanks, septic tanks constructed below the coastal water table, and numerous illegal raw sewage discharges to storm water sewers, culverts, or directly to coastal waters. Frequent violations to indicator bacteria legal limits suggest that coastal waters near Culebra's population center are chronically polluted by raw sewage pulses and that heavy rainfall may exacerbate the problem. But there is extensive evidence that standard microbial indicators can thrive in tropical freshwaters (Bermúdez \& Hazen, 1988; Rivera, Hazen \& Toranzos, 1988; Hernández-Delgado, Sierra, \& Toranzos, 1991) and soils (Santamaria \& Toranzos, 2003; Byappanahalli, Nevers, Korajkic, Staley et al., 2012; Byappanahalli, Yan, Hamilton, Ishii et al., 2012). Microbial indicators can also survive under tropical freshwater (Pérez-Rosas \& Hazen, 1989) and marine environments (Pérez-Rosas \& Hazen, 1988; Santo Domingo, 
Fuentes, \& Hazen, 1989). Therefore, fecal indicators can be recurrently present in coastal waters receiving frequent runoff pulses, and may not necessarily reflect a risk to public health (Colford, Wade, Schiff, Wright et al., 2007), but instead, may reflect recurrent runoff impacts. Microbial pollution of coastal waters has been linked to urban population density (Kocasoy, 1989; Mallin, Ensign, McIver, Shank et al., 2001), land use patterns (Mallin, Williams, Esham \& Lowe, 2000), and to water turbidity and oceanographic dynamics (Bonkosky, Hernández-Delgado, Sandoz, Robledo et al., 2009). However, there is a need to review and update coastal microbial water quality standards to more accurately address health risks to humans (Stewart, Gast, Fujioka, Solo-Gabriele et al., 2009) and to ecosystems.

Cyanobacteria were also observed on coral reefs exposed to frequent or occasional runoff pulses, although in low percent cover. Cyanobacteria can thrive in degraded coral reefs exposed to groundwater seepage (Littler, Littler, Brooks \& Lapointe, 2006), under high nutrient conditions in coastal waters (Kuffner \& Paul, 2001; Paul, Thacker, Banks \& Golubic, 2005), and in diseased coral colonies (Frías-López, Zerkle, Bonheyo \& Fouke, 2002; Klaus, Janse \& Fouke, 2011). Cyanobacteria overgrowth can also inhibit coral recruitment (Kuffner \& Paul, 2004; Kuffner, Walters, Becerro, Paul et al., 2006), and promote macroalgal dominance by interfering with grazing (Fong, Smith \& Wartian, 2006). Therefore, heavy rainfall and runoff can become a recurrent source of fecal contamination in coastal waters (Mallin, Ensign, McIver, Shank et al., 2001; Santiago-Rodríguez, Tremblay, Toledo-Hernández, González-Nieves et al., 2012), as well as of increased nutrient concentrations (Lapointe \& Clark, 1992; Cloern, 2001), which could lead to major alterations of coastal microbial communities, including coral-associated microbiome and cyanobacterial assemblages, which can result in a combination of potential adverse impacts to coral reef ecosystems, including coral diseases and mortality (Hernández-Delgado, Mercado-Molima, Alejandro-Camis, Candelas-Sánchez et al., 2014).

Altered coastal water quality can also have a paramount impact on coral-associated microorganisms. Coral-associated microbial community is highly dynamic, with seasonal fluctuations (Kimes, Johnson, Torralba, Nelson et al., 2013), but can suffer significant phase shifts throughout environmental stress gradients (Dinsdale, Pantos, Smriga, Edwards et al., 2008; Kelly, Williams, Barott, Carlson et al., 2014), and with eutrophication (Kline, Kuntz, Breitbart, Knowlton et al., 2006), bleaching and disease (Sekar, Kaczmarsky, \& Richardson, 2008; Mao-Jones, Ritchie, Jones, \& Ellner, 2010; Mouchka, Hewson, \& Harvell, 2010), and sea surface warming trends (Tracy, Koren, Douglas, Weil et al., 2015). A significant interaction between macroalgal and turf proliferation, and microbial impacts to Caribbean corals corals Orbicella annularis (Barott, Rodríguez-Mueller, Youle, Marhaver, 2012) and Porites astreoides (Vega-Thurber, Burkepile, Correa, Thurber et al., 2012) was also documented. However, mechanisms regarding how can environmental change affect host-microorganism interactions, or how can such altered interactions affect coral mortality or recovery from disturbance remain still largely unknown (Ainsworth, Vega-Thurber, \& Gates, 2009).

Water quality degradation is also a concern in shallow tropical coastal habitats due to the accumulation of sediments, nutrients and contaminants (McComb, 1995) that can foster 
microbial proliferation, potentially becoming an enterotoxigenic pathogen reservoir, particularly if there are recurrent impacts of raw sewage pulses. Sediment resuspension can fluctuate as a function of wind-or wave-driven factors, but also as a function of navigation activities on shallow soft bottoms, such as in BSA, and can be a major factor in nutrient loading processes (de Jong, 1995; de Jong \& van Raaphorst, 1995), as well as in microbe resuspension. Therefore, water quality dynamics are of paramount importance in understanding microbial population dynamics in coastal marine environments and should be an intrinsic part of standard microbial water quality and long-term ecological monitoring programs aimed at understanding causes and effects of water quality degradation in coastal communities.

Eutrophication can trigger a cascade effect affecting water quality, fostering macroalgal growth, and altering coral-associated microbial communities, which could lead to disease and mortality. This indicates that long-term changes associated to a combination of water quality decline, environmental stress, and climate change may trigger a shift in coral colonies from beneficial bacteria, and variability in the protective qualities of coral mucus, which may lead to an overgrowth of opportunistic bacteria when temperatures increase (Ritchie, 2006). Under chronic runoff pollution impacts this may result in a long-term slowly-evolving decline in coral reef ecosystem resilience, productivity, functions and benefits, including those reefs located within no-take protected areas. Bottom-up reef degradation may offset benefits of marine reserves and must be addressed to recover ecosystem resilience.

\subsection{Environmental Stress Gradient Impacts on Coral Reefs}

Environmental stress gradient impacts associated to sediment-laden, nutrient-loaded, turbid runoff pulses, in combination with raw sewage pollution pulses, and sediment bedload effects, significantly impacted coral reef benthic assemblages in Culebra Island. Behavior of turbidity and sewage pulses largely followed oceanographic and atmospheric dynamics associated to: (1) tidal flow; (2) turbidity associated to sediment resuspension; (3) wind direction and velocity; (4) southeastern wind-driven circulation and wave action; and (5) heavy rainfall events. These fluctuations were suggested by the presence of higher concentrations of microbial indicators in samples collected during strong wind-driven circulation and sediment resuspension events, and during ebbing tides, particularly after heavy rainfall and runoff. Ebbing flow at EHO caused a strong flow through largely-polluted LOB channel towards BSA and PME. Eventually, such flows move towards the northwest through CLPNR (Capella, 2004), therefore carrying over all pollution towards significant adjacent coral reef and seagrass systems within the natural reserve. Similar effects were documented in previous studies (Bonkosky, Hernández-Delgado, Sandoz, Robledo et al., 2009; Hernández-Delgado, Sandoz, Bonkosky, Mattei et al., 2010, Hernández-Delgado, Mercado-Molina, Alejandro-Camis, Candelas-Sánchez et al., 2014).

Benthic communities at sites frequently disturbed by sediment- and nutrient-laden runoff were dominated by macroalgae, dead coral surfaces, algal turf, lower coral species richness, H'c and J'c, with coral assemblages dominated by surviving patches of Porites porites. Old dead standing colonies and rodolites of threatened Acropora palmata and A. cervicornis were 
also observed. Coral recruit abundance was very limited across degraded sites. Also, sites such as PCR, where sediment bedload was a significant benthic community structuring factor, were dominated by thin sand veneers moving over reef pavement. It was also dominated by algal turf, dead coral colonies, or small colonies of ephemeral taxa such as $P$. astreoides. In contrast, sites under strong water circulation, which prevents sediment deposition, were largely dominated by higher coral species richness, H'n, J'n, CCA, and by a higher abundance of juvenile corals and sponges. These patterns reflected variation associated to gradient impacts and were consistent with previous observations in the Caribbean (Tomascik \& Sander, 1987a; Tomascik, 1991).

Turbid waters and raw sewage pollution have been pointed out as one of the causes of coral reef and fish community decline in Culebra (Hernández-Delgado, Rosado-Matías \& Sabat, 2006). Extreme rainfall events have also been pointed out as sources of sediment-laden runoff (Otaño-Cruz, Montañez-Acuña, Torres-López, Hernández-Figueroa et al., 2017) and coral mortality (Hernández-Delgado, Mercado-Molina, Alejandro-Camis, Candelas-Sánchez et al., 2014). Increasing chronic non-point source sewage pollution may result in permanent water quality degradation impairing most human direct (e.g., swimming, other types of direct contact recreation) and indirect (e.g., fishing) uses. In this context, it is important to identify non-point sources of fecal contamination to prevent diseases and improve water quality (Scott, Rose, Jenkins, Farrah et al., 2002), as well as to manage human uses of coastal waters. Such factors can have profound long-term irreversible effects in the integrity and community structure of coral reefs (Cloern, 2001), as well as in the composition of marine food webs (Livingston, 2001). Therefore, it could offset the potential benefits of no-take protected areas.

\subsection{Implications of Environmental Stress on Coral Reef Conservation in a Changing World}

The impacts of coastal water quality degradation associated to human-driven non-point pollution sources have been extensively reviewed (Brown \& Howard, 1985; Pastorok \& Byliard, 1985; McComb, 1995; Cloern, 2001; Livingston, 2001), although Szmant (2002) suggested that eutrophication associated to natural upwelling can be significant as well. Non-point source pollution can result in eutrophication, increasing biological oxygen demand, and causing hypoxia and anoxia (Kennish, 2002; Rabalais, Turner, Díaz, \& Justić, 2009), as well as increased concentrations of organic carbon, nitrogen, chlorophyll- $a$, phospholipids, and hydrolytic enzymatic activities (Köster, Dahlke, \& Meyer-Reil., 1997). Also, it may result in a chronic increase in water turbidity, declining sunlight penetration, and in a chronic deterioration of sediment quality (Livingston, 2001). Eutrophication may also foster phytoplankton blooms (Bell, 1992; McComb, 1995; Arhonditsis, Karydis, \& Tsirtsis, 2003), harmful algal blooms (Anderson, Glibert, \& Burkholder, 2002), rapid macroalgal growth (Naim, 1993), a long-term decline in fisheries productivity (Hodgkiss \& Yim, 1995), and a net decline in seagrass (Duarte, 1995; Tomasko, Dawes \& Hall, 1996) and coral reef communities (Lapointe \& Clark, 1992; Cloern, 2001; Díaz-Ortega \& Hernández-Delgado, 2014; Duprey, Yasuhara, \& Baker, 2016). Corals are particularly susceptible to eutrophication as a result of declining growth rates (Tomascik \& Sander, 1985; Tomascik, 1990), reproductive output (Tomascik \& Sander, 1987b), larval settlement rates (Tomascik, 1991), increased incidence of diseases (Kaczmarsky, Draud, \& Williams, 2005), altered 
microbiology (Kline, Kuntz, Breitbart, Knowlton et al., 2006), and increased susceptibility to bleaching (Vega-Thurber, Burkepile, Fuchs, Shantz et al., 2013; Wiedenmann et al., 2013), and mortality (Pastorok \& Byliard, 1985), often impacting benthic community structure (Tomascik \& Sander, 1987a). These impacts are often confounded with sedimentation effects (Rogers, 1990; Meesters, Bak, Westmacott, Ridgley et al., 1998; Risk, 2014), and can be readily magnified by climate change-related factors (Ateweberhan, Feary, Keshavmurthy, Chen et al., 2013).

Sediment delivery from adjacent watersheds is also a concern (Brown \& Howard, Rogers, 1990; Risk, 2014). Sub-surface processes and unpaved road erosion are the dominant processes for exporting fine sediments to tropical coastal habitats (MacDonald, Anderson, \& Dietrich, 2007). Bartley, Bainbridge, Lewis, Kroon et al. (2014) suggested that at least $75 \%$ land cover should be maintained to reduce erosion potential. Ramos-Scharrón (2012) recommended improving the effectiveness of drainage on steep roads as another alternative to reduce sediment-loaded runoff. Terrestrial sediments often transported to offshore coral reefs is generally the clay to fine silt $(<4-16 \mu \mathrm{m})$ fraction, yet there is considerable potential for impacts of other terrestrially derived sediment fractions $(<63 \mu \mathrm{m})$ to be deposited in shallow, near-shore coral reefs, and remobilized during wind-, tidal-, and wave-driven re-suspension (Bartley, Bainbridge, Lewis, Kroon et al., 2014; Otaño-Cruz, Montañez-Acuña, Torres-López, Hernández-Figueroa et al., 2017). Fine-grained and dark-colored sediments at high suspended-sediment concentrations can also significantly attenuate photosynthetically available radiation (PAR) (Storlazzi, Norris, \& Rosenberger, 2015). Sedimentation can result in increasing turbidity, declining light levels, and declining calcification rates, linear extension, colony surface area, and volume of Staghorn coral, Acropora cervicornis (Enochs, Manzello, Carlton, Schopmeyer et al., 2014). Anthropogenic sediment deposition can also reduce photosynthetic activities of corals symbiotic algae, affecting the viability of corals (Phillip \& Fabricius, 2003). Even low sediment deposition on newly settled, highly-sensitive coral recruits can be significantly detrimental (Moeller, Nietzer, Schils, \& Shupp, 2016). Sediments can also modify nutrient and herbivore control of macroalgae in ways that differ among species (Clausing, Bittick, Fong \& Fong, 2016), therefore, resulting in adverse impacts to reef productivity.

The combined effects of local anthropogenic stressors with large-scale stressors such as sea surface warming, ocean acidification, and sea level rise have increased over recent decades. Sea surface warming and ocean acidification can trigger bleaching and lower reef productivity (Anthony, Kline, Díaz-Pulido, Dove et al., 2008), lowering coral reef resilience (Anthony, Maynard, Díaz-Pulido, Mumby et al., 2011). Their projected synergistic impacts may result in a significant degradation of coastal water quality, ecosystem functions and benefits, in declining coastal resiliency and local economies, and in degraded community-based livelihoods (Hernández-Delgado, 2015). It has also been shown that different combinations of ubiquitous anthropogenic stressors (e.g., sedimentation, eutrophication, overfishing) can interactively influence natural community recovery from disturbance and may alter species compositions in the resulting community, with regime shifts from coral to macroalgal dominance (Gil, Goldenberg, Bach, Mills et al, 2016). 
Further, reducing top-down control (e.g., overfishing), in combination with sediment addition can have a significantly strong effect on coral reef benthic assemblages, leading to approximately three times greater algal biomass (Muthukrishnang \& Fong, 2014). Therefore, alleviation of most local stress factors such as nutrient discharges, sedimentation, and overfishing becomes imperative if sufficient overall resilience of reefs to climate change is to be restored (Ateweberhan, Feary, Keshavmurthy, Chen et al., 2013). Nevertheless, it still remains critical to tackle down the more fundamental problem of reducing atmospheric $\mathrm{CO}_{2}$ emissions for permanently recovering coral reef ecosystem resilience (Côtè \& Darling, 2010).

\section{Conclusions}

Coastal waters in Culebra Island were impacted by non-point source fecal pollution, sediment-laden, nutrient-loaded, turbid runoff, and sediment bedload, creating a strong gradient of impacts on shallow coral reef benthic communities. Variable sources of pollution included (1) malfunctioning septic tanks, (2) illegal sewage discharges from private houses and businesses (i.e., restaurants), (3) raw sewage-polluted stormwater sewers; and (4) widespread deforestation for construction of private houses and unpaved roads. Poorly planned land uses remain largely unsustainable (Hernández-Delgado, Ramos-Scharrón, Guerrero, Lucking et al., 2012), resulting in significant alterations of watersheds, increasing soil erosion and sediment delivery potential to adjacent coastal waters (Ramos-Scharrón, Amador \& Hernández-Delgado, 2012; Otaño-Cruz, Montañez-Acuña, Torres-López, Hernández-Figueroa et al., 2017). These impacts affected CLPNR, resulting in a long-term regime shift in coral reef benthic community structure, with concomitant effects on ecosystem resilience and functions, offsetting the benefits coral reefs along CLPNR.

There is an imperative need to design and implement integrated watershed management approaches, in combination with coastal management strategies, to address marine, coastal-maritime zone, and watershed management needs to reduce sediment delivery, and fecal and runoff pollution impacts along the coast. Point and non-point sources of pollution, and areas subjected to strong soil erosion and sediment delivery potential need to be identified, geo-referenced and mapped. Such information may provide important tools to help prioritize management actions and reorganize land use following a sustainable land use plan. Preventing anthropogenic sediment reaching nearshore coral reefs requires an improved understanding of the specific characteristics, sources and processes generating the anthropogenic sediment, so that effective watershed management strategies can be implemented (Bartley, Bainbridge, Lewis, Kroon et al., 2014). Therefore, such components need to be incorporated into integrated, multi-disciplinary research and long-term monitoring programs. Lack of standardized data is fundamental to understand processes and to parameterize erosion models (Fu, Newham, \& Ramos-Scharrón, 2010). Such tools need also to be incorporated into management frameworks and decision-making processes.

There is also a strong need to implement immediate erosion-control management practices and watershed reforestation. This could be accomplished throughout the implementation of a "green certification" program for construction workers and heavy machinery operators, in combination with steep dirt road and drainage repair, and a massive community-based 
restoration program. Also, cooperative approaches may help to improve cost effectiveness of any watershed management and restoration effort (Oleson, Falinsky, Lecky, Rowe et al., 2017). A watershed restoration program has been already designed for Culebra Island (Sturm et al., 2014). However, its implementation has still been limited to small isolated efforts, mostly due to economic limitations. It is paramount to significantly reduce sedimentation impacts in sensitive habitats that serve as nursery and feeding grounds of commercially important fish species, as well as for the endangered Caribbean manatee (Trichechus manatus), Hawksbill turtle (Eretmochelys imbricata), Green turtle (Chelonia mydas), and threatened Acroporid corals. Shallow coastal coral reefs and seagrass communities also harbor nursery grounds of a myriad of fish and macroivertebrate species of commercial significance. Such is the case of areas adjacent to BTA, PRA, PME, and BSA.

Coastal and marine ecosystems are interconnected with adjacent catchment areas through hydrological connections. However, many coastal ecosystems are in a poor state, driven by several factors including poor land uses, highly modified watersheds, densification, and raw sewage pollution. Sediment deposited on shallow coastal bottoms can be frequently resuspended by wind-driven wave action, resulting in significant bedload effects. Altered land uses have largely resulted in modified watersheds and coastal ecosystems, and in disrupting drainage and hydrological connections (Otaño-Cruz, Montañez-Acuña, Torres-López, Hernández-Figueroa et al., 2017). These ecohydrological changes have led to declining water quality in catchment waterways and increases in the loads of sediments and pollutants delivered to coastal waters. Management strategies need to be more aggressive, integrative and participatory, and aimed at improving land use management and governance. There is still a need to protect, maintain and restore coastal ecosystem services, functions, land-sea connectivity, and ecosystem resilience if the values of coral reefs are to be retained in the long term (Waterhouse, Brodie, Lewis, Audas, 2016).

There is also a need to address coral microbial community dynamics. Coral microbes can be excellent sentinels or an early warning sign of stress in coral reef ecosystems (Stewart et al., 2008). In addition, there is a need to experimentally test the resilience of corals to recurrent runoff conditions in the context of increasing sea surface temperature and ocean acidification. It would be important to address coral survival threshold points in the context of changing environmental and climate conditions, and to address the viability of coral reef restoration success. In face of projected recurrent environmental impacts associated to climate change, frequent non-point source pollution episodes can result in a magnified long-term decline of coastal environmental conditions. Such declines could further result in irreversible benthic community regime shifts, negatively affecting ecosystem functions, degrading essential fish habitats and losing the economic value of these ecosystems. Reducing impacts by local anthropogenic stressors becomes increasingly more important to minimize sources of stress to local coral reefs and reduce their vulnerability to climate change-related stress.

\section{Acknowledgments}

This study was made possible thanks to NOAA funds awarded to the Puerto Rico Department of Natural and Environmental Resources, Coral Reef Conservation Program, NOAA Award 
Number NA06NOS4190108 (Task CRI-9) provided to J. Norat-Ramírez and H. Mattei. Also, partial funds were provided to E.A. Hernández-Delgado by the NOAA/CSCOR sponsored Caribbean Coral Reef Institute of the University of Puerto Rico (NA07NOS4000192), and by the University of Puerto Rico's Central Administration Bridge Funds to E.A. Hernández-Delgado though the Center for Applied Tropical Ecology and Conservation. Our appreciation to Jorge “Guilín” Peña and Brian O’Hanlon for their support through the project.

\section{References}

Ainsworth, T. D., Thurber, R. V., \& Gates, R. D. (2010). The future of coral reefs: a microbial perspective. Trends in Ecology \& Evolution, 25, 233-240.

https://doi.org/10.1016/j.tree.2009.11.001

American Public Health Association (1992). Standard Methods for the Examination of Water and Wastewater, 18th ed. American Public Health Association, Washington, DC.

Anderson, D. M., Glibert, P. M., \& Burkholder, J. M. (2002). Harmful algal blooms and eutrophication: nutrient sources, composition, and consequences. Estuaries, 25, 704-726. https://doi.org/10.1007/BF02804901

Anderson, M. Gorley, R. Clarke, K. (2008). PERMANOVA+ for PRIMER: Guide to Software and Statistical Methods. PRIMER-E: Plymouth.

Anthony, K. R., Kline, D. I., Díaz-Pulido, G., Dove, S., \& Hoegh-Guldberg, O. (2008). Ocean acidification causes bleaching and productivity loss in coral reef builders. Proceedings of the National Academy of Sciences, 105, 17442-17446. https://doi.org/10.1073/pnas.0804478105

Anthony, K., Maynard, J. A., Díaz-Pulido, G., Mumby, P. J., Marshall, P. A., Cao, L., \& Hoegh-Guldberg, O. (2011). Ocean acidification and warming will lower coral reef resilience. Global Change Biology, 17, 1798-1808. https://doi.org/10.1111/j.1365-2486.2010.02364.x

Arhonditsis, G., Karydis, M., \& Tsirtsis, G. (2003). Analyisis of phytoplankton community structure using similarity indices: A new methodology for discriminating among eutrophication levels in coastal marine ecosystems. Environmental Management, 31, 619-632. https://doi.org/10.1007/s00267-002-2903-4

Ateweberhan, M., Feary, D. A., Keshavmurthy, S., Chen, A., Schleyer, M. H., \& Sheppard, C. R. (2013). Climate change impacts on coral reefs: synergies with local effects, possibilities for acclimation, and management implications. Marine Pollution Bulletin, 74, 526-539.

https://doi.org/10.1016/j.marpolbul.2013.06.011

Ballantine, D. L., Appeldoorn, R. S., Yoshioka, P., Weil, E., Armstrong, R., García, J.R., Otero, E., Pagán, F., Sherman, C., Hernández-Delgado, E.A., Bruckner, A., \& Lilyestrom, C. (2008). Biology and ecology of Puerto Rican coral reefs. 375-406. In, B.M. Riegl \& R.E. Dodge (eds.), Coral Reefs of the World, Vol. I. Coral Reefs of the USA, Springer-Science + Business Media B.V. 803pp. https://doi.org/10.1007/978-1-4020-6847-8_9

Barott, K. L., Rodriguez-Mueller, B., Youle, M., Marhaver, K. L., Vermeij, M. J., Smith, J. E., \& Rohwer, F. L. (2012). Microbial to reef scale interactions between the reef-building coral 
Montastraea annularis and benthic algae. Proceedings of the Royal Society of London B: Biological Sciences, 279, 1655-1664. https://doi.org/10.1098/rspb.2011.2155

Bartley, R., Bainbridge, Z. T., Lewis, S. E., Kroon, F.J., Wilkinson, S.N., Brodie, J.E. and Silburn, D.M., 2014. Relating sediment impacts on coral reefs to watershed sources, processes and management: A review. Science of the Total Environment, 468, 1138-1153. https://doi.org/10.1016/j.scitotenv.2013.09.030

Bellard, C., Bertelsmeier, C., Leadley, P., Thuiller, W., \& Courchamp, F. (2012). Impacts of climate change on the future of biodiversity. Ecology Letters, 15, 365-377. https://doi.org/10.1111/j.1461-0248.2011.01736.x

Bellwood, D. R., Hughes, T. P., Folke, C., \& Nyström, M. (2004). Confronting the coral reef crisis. Nature, 429, 827-833. https://doi.org/10.1038/nature02691

Bermúdez, M. A., \& Hazen, T. C. (1988) Phenotypic and genotypic comparison of Escherichia coli from pristine tropical waters. Applied and Environmental Microbiology, 54, 979-983. http://aem.asm.org/content/54/4/979.full.pdf+html

Bonkosky, M., Hernández-Delgado, E. A., Sandoz, B., Robledo, I. E., Norat-Ramírez, J., \& Mattei, H. (2009). Detection of spatial fluctuations of non-point source fecal pollution in coral reef surrounding waters in southwestern Puerto Rico using PCR-based assays. Marine Pollution Bulletin, 58, 45-54. https://doi.org/10.1016/j.marpolbul.2008.09.008

Brown, B. E., \& Howard, L. (1985). Assessing the effects of "stress" on reef corals. Advances in Marine Biology, 22, 1-63. https://doi.org/10.1016/S0065-2881(08)60049-8

Buddemeier, R. W., Jokiel, P. L., Zimmerman, K. M., Lane, D. R., Carey, J. M., Bohling, G. C., \& Martinich, J. A. (2008). A modeling tool to evaluate regional coral reef responses to changes in climate and ocean chemistry. Limnology and Oceanography: Methods, 6, 395-411. https://doi.org/10.4319/lom.2008.6.395

Buddemeier, R. W., Lane, D. R., \& Martinich, J. A. (2011). Modeling regional coral reef responses to global warming and changes in ocean chemistry: Caribbean case study. Climatic Change, 109, 375-397. https://doi.org/10.1007/s10584-011-0022-z

Byappanahalli, M. N., Nevers, M. B., Korajkic, A., Staley, Z. R., \& Harwood, V. J. (2012a). Enterococci in the environment. Microbiology and Molecular Biology Reviews, 76, 685-706. https://doi.org/10.1128/MMBR.00023-12

Byappanahalli, M. N., Yan, T., Hamilton, M. J., Ishii, S., Fujioka, R. S., Whitman, R. L., \& Sadowsky, M. J. (2012b). The population structure of Escherichia coli isolated from subtropical and temperate soils. Science of the Total Environment, 417, 273-279.

https://doi.org/10.1016/j.scitotenv.2011.12.041

Capella, J. A. (2004). Culebra final current meter deployment report. Culebra OOCA Studies, Dept. Marine Science, UPR-Mayaguez. 14 pp. + App.

Carilli, J. E., Norris, R. D., Black, B. A., Walsh, S. M., \& McField, M. (2009). Local stressors 
reduce coral resilience to bleaching. Plos One, 4(7), e6324.

https://doi.org/10.1371/journal.pone.0006324

Clarke, K. Gorley, R. Somerfield, P. Warwick, R. (2014). Change in Marine Communities: An Approach to Statistical Analysis and Interpretation. 3rd edition. PRIMER-E: Plymouth.

Clausing, R. J., Bittick, S. J., Fong, C. R., \& Fong, P. (2016). Sediments influence accumulation of two macroalgal species through novel but differing interactions with nutrients and herbivory. Coral Reefs, 35, 1297-1309.

https://doi.org/10.1007/s00338-016-1477-1

Cloern, J. E. (2001). Our evolving conceptual model of the coastal eutrophication model. Marine Ecology Progress Series, 210, 223-253. https://doi.org/10.3354/meps210223

Colford Jr, J. M., Wade, T. J., Schiff, K. C., Wright, C. C., Griffith, J. F., Sandhu, S. K., Burns, S., Sobsey, M., Lovelace, G., \& Weisberg, S. B. (2007). Water quality indicators and the risk of illness at beaches with nonpoint sources of fecal contamination. Epidemiology, 18, 27-35. https://doi.org/10.1097/01.ede.0000249425.32990.b9

Côté, I. M., \& Darling, E. S. (2010). Rethinking ecosystem resilience in the face of climate change. PLoS Biol, 8(7), e1000438. https://doi.org/10.1371/journal.pbio.1000438

de Jong, V. N. \& van Raaphorst, W. (1995). Eutrophication of the Dutch Wadden Sea (Western Europe), an estuarine area controlled by the River Rhine. 81-108. In, A. J. McComb (ed.), Eutrophic Shallow Estuaries and Lagoons. CRC Press, Boca Raton, FL, 240 pp.

de Jong, V. N. (1995). The Ems estuary, the Netherlands. 81-108. In, A. J. McComb (ed.), Eutrophic Shallow Estuaries and Lagoons. CRC Press, Boca Raton, FL, 240 pp.

https://www.crcpress.com/Eutrophic-Shallow-Estuaries-and-Lagoons/McComb/p/book/9780 849368394

Díaz-Ortega, G., \& Hernández-Delgado, E. A. (2014). Unsustainable land-based source pollution in a climate of change: a roadblock to the conservation and recovery of Elkhorn Coral Acropora palmata (Lamarck 1816). Natural Resources, 5, 561-581. https://doi.org/10.4236/nr.2014.510050

Dinsdale, E.A., Pantos, O., Smriga, S., Edwards, R. A., Angly, F., Wegley, L., Hatay, M., Hall, D., Brown, E., Haynes, M., \& Krause, L. (2008). Microbial ecology of four coral atolls in the Northern Line Islands. PloS One, 3, .e1584. https://doi.org/10.1371/journal.pone.0001584

Duarte, C. M. (1995). Submerged aquatic vegetation in relation to different nutrient regimes. Ophelia, 41, 87-112. https://doi.org/10.1080/00785236.1995.10422039

Duprey, N. N., Yasuhara, M., \& Baker, D. M. (2016). Reefs of tomorrow: eutrophication reduces coral biodiversity in an urbanized seascape. Global Change Biology, 22, 3550-3565. https://doi.org/10.1111/gcb.13432

Edmunds, P. J. (2013). Decadal-scale changes in the community structure of coral reefs of St. John, US Virgin Islands. Marine Ecology Progress Series, 489, 107-123. 
https://doi.org/10.3354/meps10424

Edmunds, P. J., \& Elahi, R. (2007). The demographics of a 15-year decline in cover of the Caribbean reef coral Montastraea annularis. Ecological Monographs, 77, 3-18. https://doi.org/10.1890/05-1081

Elmhirst, T., Connolly, S. R., \& Hughes, T. P. (2009). Connectivity, regime shifts and the resilience of coral reefs. Coral Reefs, 28, 949-957.

https://doi.org/10.1007/s00338-009-0530-8

Ennis, R. S., Brandt, M. E., Grimes, K. R. W., \& Smith, T. B. (2016). Coral reef health response to chronic and acute changes in water quality in St. Thomas, United States Virgin Islands. Marine Pollution Bulletin, 111, 418-427.

https://doi.org/10.1016/j.marpolbul.2016.07.033

Enochs, I. C., Manzello, D. P., Carlton, R., Schopmeyer, S., Van Hooidonk, R., \& Lirman, D. (2014). Effects of light and elevated pCO2 on the growth and photochemical efficiency of Acropora cervicornis. Coral Reefs, 33, 477-485. https://doi.org/10.1007/s00338-014-1132-7

Fabricius, K. E., \& D. McCorry. (2006). Changes in octocoral communities and benthic cover along a water quality gradient in the reefs of Hong Kong. Marine Pollution Bulletin, 52, 22-33. https://doi.org/10.1016/j.marpolbul.2005.08.004

Fabricius, K. E., \& Wolanski, E. (2000). Rapid smothering of coral reef organisms by muddy marine snow. Estuarine and Coastal Marine Science, 50, 115-120.

https://doi.org/10.1006/ecss.1999.0538

Foden, W., Mace, G. M., Vié, J. C., Angulo, A., Butchart, S. H. M., DeVantier, L., Dublin, H.T., Gutsche, A., Stuart, S., \& Turak, E. (2008). Species susceptibility to climate change impacts. Wildlife in a changing world-an analysis of the 2008 IUCN Red List of threatened species, 77. https://portals.iucn.org/library/sites/library/files/documents/RL-2009-001.pdf

Fong, P., Smith, T. B., \& Wartian, M. J., (2006). Epiphytic cyanobacteria maintain shifts to macroalgal dominance on coral reefs following ENSO disturbance. Ecology, 87, 1162-1168. https://doi.org/10.1890/0012-9658(2006)87[1162:ECMSTM]2.0.CO;2

Freeman, L. A., Kleypas, J. A., \& Miller, A. J. (2013). Coral reef habitat response to climate change scenarios. PloS one, 8(12), e82404. https://doi.org/10.1371/journal.pone.0082404

Frías-López, J., Zerkle, A. L., Bonheyo, G. T., \& Fouke, B. W. (2002). Partitioning of bacterial communities between seawater and healthy, black band diseased, and dead coral surfaces. Applied and Environmental Microbiology, 68, 2214-2228.

https://doi.org/10.1128/AEM.68.5.2214-2228.2002

Fu, B., Newham, L. T., \& Ramos-Scharrón, C. E. (2010). A review of surface erosion and sediment delivery models for unsealed roads. Environmental Modelling \& Software, 25, 1-14. https://doi.org/10.1016/j.envsoft.2009.07.013

García, J. R., Morelock, J., Castro, R., Goenaga, C., \& Hernández, E. (2003). Puerto Rican 
reefs: Research synthesis, present threats and management perspectives. 111-130. In, J. Cortés (ed.), Latin American Coral Reefs. Elsevier Publ., Amsterdam, Holland, 497 pp.

García-Sais, J. R., Appeldoorn, R., Batista, T., Bauer, L., Bruckner, A., Caldow, C., Carruba, L.M., Corredor, J., Díaz, E., Lyliestrom, C., García-Moliner, G., Hernández-Delgado, E., Menza, C., Morell, J., Pait, A., Sabater, J., Weil, E., Williams, E., \& Williams, S. (2008). The state of coral reef ecosystems in Puerto Rico. Pp. 75-116. In, J.E. Waddell \& A.M. Clarke (eds.), The State of Coral Reef Ecosystems of the United States and Pacific Freely Associated States: 2008. NOAA Tech. Mem. NOS NCCOS 73. NOAA/NCCOS Center for Coastal Monitoring and Assessment's Biogeography Team. Silver Spring, MD, 569 pp.

https://coastalscience.noaa.gov/research/docs/CoralReport2008.pdf

Gardner, T. A., Côté, I. M., Gill, J. A., Grant, A., \& Watkinson, A. R. (2003). Long-term region-wide declines in Caribbean corals. Science, 301, 958-960.

https://doi.org/10.1126/science.1086050

Gardner, T. A., Côté, I. M., Gill, J. A., Grant, A., \& Watkinson, A. R. (2005). Hurricanes and Caribbean coral reefs: impacts, recovery patterns, and role in long - term decline. Ecology, 86, 174-184. https://doi.org/10.1890/04-0141

Gil, M. A., Goldenberg, S. U., Bach, A. L. T., Mills, S. C., \& Claudet, J. (2016). Interactive effects of three pervasive marine stressors in a post-disturbance coral reef. Coral Reefs, 35, 1281-1293. https://doi.org/10.1007/s00338-016-1489-x

Goenaga, C., \& Cintrón, G. (1979). Inventory of the Puerto Rican Coral Reefs. Report submitted to the Coastal Zone Management of the Department of Natural Resources, San Juan, PR, 190 pp.

https://drna.pr.gov/wp-content/uploads/2017/02/Goenaga-and-Cintron-1979-Inventory-of-the -Puerto-Rican-coral-reefs.pdf

Hernández-Delgado E. A., Ramos-Scharrón, C.E., Guerrero, C., Lucking, M.A., Laureano, R., Méndez-Lázaro, P.A., \& Meléndez-Díaz, J.O. (2012). Long-term impacts of tourism and urban development in tropical coastal habitats in a changing climate: Lessons learned from Puerto Rico. 357-398. In M. Kasimoglu (ed.), Visions from Global Tourism Industry-Creating and Sustaining Competitive Strategies. Intech Publications.

http://www.intechopen.com/books/visions-for-global-tourism-industry-creating-and-sustainin g-competitive-strategies/long-term-impacts-of-non-sustainable-tourism-and-urban-developme nt-in-tropical-coastal-habitats-in-a

Hernández-Delgado, E. A. (2003a). Suplemento técnico al Plan de Manejo para la Reserva Natural del Canal Luis Peña, Culebra, Puerto Rico. I. Caracterización de habitáculos. Informe Técnico sometido al Programa de Manejo de la Zona Costanera, Departamento de Recursos Naturales y Ambientales. San Juan, PR, 109 pp.

https://www.academia.edu/258928/Suplemento_tecnico_al_Plan_de_Manejo_de_la_Reserva _Natural_Canal_de_Luis_Pe\%C3\%B1a_Culebra_Puerto_Rico_I._Caracterizaci\%C3\%B3n_d e_habit\%C3\%A1culos 


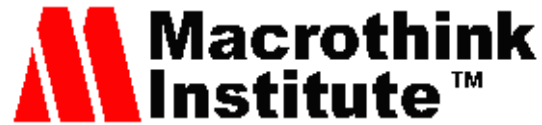

Hernández-Delgado, E. A. (2003b). Suplemento técnico al Plan de Manejo para la Reserva Natural del Canal Luis Peña, Culebra, Puerto Rico. IV. Alternativas de demarcación y de zonificación. Informe Técnico sometido al Programa de Manejo de la Zona Costanera, Departamento de Recursos Naturales y Ambientales. San Juan, PR, 48 pp.

https://www.academia.edu/258960/Suplemento_tecnico_al_Plan_de_Manejo_de_la_Reserva _Natural_Canal_de_Luis_Pe\%C3\%B1a_Culebra_Puerto_Rico_IV._Alternativas_de_zonifica ci\%C3\%B3n_y_demarcaci\%C3\%B3n

Hernández-Delgado, E. A. (2004). Análisis del estado de los recursos y de la situación ambiental actual de la Reserva Natural del Canal Luis Peña, Culebra, P.R. Informe Técnico sometido a la Autoridad de Conservación y Desarrollo de Culebra, Culebra, PR, 133 pp. https://www.academia.edu/258964/An\%C3\%A1lisis_del_estado_de_los_recursos_y_de_la_si tuaci\%C3\%B3n_ambiental_actual_de_la_Reserva_Natural_del_Canal_Luis_Pe\%C3\%B1a_C ulebra_PR

Hernández-Delgado, E. A. (2005). Historia natural, caracterización, distribución y estado actual de los arrecifes de coral Puerto Rico. 281-356. In, R.L. Joglar (Ed.), Biodiversidad de Puerto Rico: Vertebrados Terrestres y Ecosistemas. Serie Historia Natural. Editorial Instituto de Cultura Puertorrique-a, San Juan, PR, 563 pp.

Hernández-Delgado, E. A., \& Rosado-Matías, B. J. (2003). Suplemento técnico al Plan de Manejo para la Reserva Natural del Canal Luis Peña, Culebra, Puerto Rico. II. Inventario biológico. Informe Técnico sometido al Programa de Manejo de la Zona Costanera, Departamento de Recursos Naturales y Ambientales. San Juan, PR, 60 pp.

https://www.academia.edu/258933/Suplemento_tecnico_al_Plan_de_Manejo_de_la_Reserva _Natural_Canal_de_Luis_Pe\%C3\%B1a_Culebra_Puerto_Rico_II._Inventario_biol\%C3\%B3 gico

Hernández-Delgado, E. A., \& Sabat, A. M. (2000). Ecological status of essential fish habitats through an anthropogenic environmental stress gradient in Puerto Rican coral reefs. Proceeding of the Gulf Caribbean Fisheries Institute, 51, 457-470.

http://aquaticcommons.org/13373/1/gcfi_51-36.pdf

Hernández-Delgado, E. A., Alicea-Rodríguez, L., Toledo-Hernández, C. G., \& Sabat, A.M. (2000). Baseline characterization of coral reef epibenthic and fish communities within the proposed Culebra Island Marine Fishery Reserve, Puerto Rico. Proceedings of the Gulf Caribbean Fisheries Institute, 51, 537-556.

http://aquaticcommons.org/13380/1/gcfi_51-43.pdf

Hernández-Delgado, E. A., González-Ramos, C. M., \& Alejandro-Camis, P. J. (2014). Large-scale coral recruitment patterns on Mona Island, Puerto Rico: evidence of a transitional community trajectory after massive coral bleaching and mortality. Revista de Biología Tropical, 62, 283-298. http://dx.doi.org/10.15517/rbt.v62i0.15901

Hernández-Delgado, E. A., Mercado-Molina, A. E., Alejandro-Camis, P. J., Candelas-Sánchez, F., Fonseca-Miranda, J. S., González-Ramos, C. M., Guzmán-Rodríguez, R., Mège, P., Monta-ez-Acu-a, A. A., Olivo-Maldonado, I., \& Otaño-Cruz, A. (2014). 


\section{$\triangle$ Macrothink}

Community-based coral reef rehabilitation in a changing climate: Lessons learned from hurricanes, extreme rainfall, and changing land use impacts. Open Journal of Ecology, 4, 918-944. https://doi.org/10.4236/oje.2014.414077

Hernández-Delgado, E. A., Rosado-Matías, B. J., \& Sabat, A.M. (2006). Management failures and coral decline threatens fish functional groups recovery patterns in the Luis Peña Channel No-Take Natural Reserve, Culebra Island, PR. Proceedings of the Gulf and Caribbean Fisheries Institute, 57, 577-605.

http://aquaticcommons.org/13898/1/gcfi_57-41.pdf

Hernández-Delgado, E. A., Sandoz, B., Bonkosky, M., Mattei, H., \& Norat, J. (2010). Impacts of non-point source sewage pollution in Elkhorn coral, Acropora palmata (Lamarck), assemblages of the southwestern Puerto Rico shelf. Proceedings of the $11^{\text {th }}$ International Coral Reefs Symposium, 747-751.

http://www.nova.edu/ncri/11icrs/proceedings/files/m18-16.pdf

Hernández - Delgado, E. A., Sierra, M. L., \& Toranzos, G.A. (1991). Coliphages as alternate indicators of fecal contamination in tropical waters. Environmental Toxicology, 6, 131-143. https://doi.org/10.1002/tox.2530060203

Hernández-Delgado, E.A. (2000). Effects of anthropogenic stress gradients in the structure of coral reef epibenthic and fish communities. Ph.D. Dissertation, Department of Biology, University of Puerto Rico, Río Piedras, P.R. 330 pp.

Hernández-Pacheco, R., Hernández-Delgado, E. A., \& Sabat, A. M. (2011). Demographics of bleaching in a major Caribbean reef - building coral: Montastraea annularis. Ecosphere, 2, 1-13. https://doi.org/10.1890/ES10-00065.1

Hodgkiss, I. J., Yim, W. S. (1995). A case study of Tolo Harbour, Hong Kong. 41-58. In, A. J. McComb (ed.), Eutrophic Shallow Estuaries and Lagoons. CRC Press, Boca Raton, FL, 240 pp.

https://www.crcpress.com/Eutrophic-Shallow-Estuaries-and-Lagoons/McComb/p/book/9780 849368394

Hoegh-Guldberg, O. (1999). Climate change, coral bleaching and the future of the world's coral reefs. Marine and Freshwater Research, 50, 839-866. https://doi.org/10.1071/MF99078

Hoeke, R. K., Jokiel, P. L., Buddemeier, R. W., \& Brainard, R. E. (2011). Projected changes to growth and mortality of Hawaiian corals over the next 100 years. PloS One, 6(3), e18038. https://doi.org/10.1371/journal.pone.0018038

https://doi.org/10.1016/0025-326X(90)90645-O

https://sustainabledevelopment.un.org/content/documents/1891-Status\%20and\%20Trends\%2 0of\%20Caribbean\%20Coral\%20Reefs-\%201970-2012-2014Caribbean\%20Coral\%20Reefs\% 20-\%20Status\%20Report\%201970-2012\%20(1).pdf

https://www.crcpress.com/Eutrophic-Shallow-Estuaries-and-Lagoons/McComb/p/book/9780 849368394 
https://www.researchgate.net/publication/237269214_PUERTORICAN_REEFS_research_sy nthesis_present_threats_and_management_perspectives

Hughes, T. P., Rodrigues, M. J., Bellwood, D. R., Ceccarelli, D., Hoegh-Guldberg, O., McCook, L., Moltschaniwskyj, N., Pratchett, M. S., Steneck, R. S., \& Willis, B. (2007). Phase shifts, herbivory, and the resilience of coral reefs to climate change. Current Biology, 17, 360-365. https://doi.org/10.1016/j.cub.2006.12.049

Jackson, J., Donovan, M., Cramer, K., \& Lam, V. (2014). Status and trends of Caribbean coral reefs: 1970-2012. Global Coral Reef Monitoring Network.

Jones, G. P., McCormick, M. I., Srinivasan, M., \& Eagle, J. V. (2004). Coral decline threatens fish biodiversity in marine reserves. Proceedings of the National Academy of Sciences of the United States of America, 101, 8251-8253. https://doi.org/10.1073/pnas.0401277101

Kaczmarsky, L. T., Draud, M., \& Williams, E. H. (2005). Is there a relationship between proximity to sewage effluent and the prevalence of coral disease? Caribbean Journal of Science, 41, 124-137.

https://www.researchgate.net/publication/228856970_Is_there_a_relationship_between_proxi mity_to_sewage_effluent_and_the_prevalence_of_coral_disease_Carib_J_Sci

Kelly, L. W., Williams, G. J., Barott, K. L., Carlson, C. A., Dinsdale, E. A., Edwards, R. A., Haas, A. F., Haynes, M., Lim, Y. W., McDole, T., \& Nelson, C. E. (2014). Local genomic adaptation of coral reef-associated microbiomes to gradients of natural variability and anthropogenic stressors. Proceedings of the National Academy of Sciences, 111, 10227-10232. https://doi.org/10.1073/pnas.1403319111

Kennish, M. J. (2002). Environmental threats and environmental future of estuaries. Environmental Conservation, 29, 78-107. https://doi.org/10.1017/S0376892902000061

Kimes, N. E., Johnson, W. R., Torralba, M., Nelson, K. E., Weil, E., \& Morris, P. J. (2013). The Montastraea faveolata microbiome: ecological and temporal influences on a Caribbean reef - building coral in decline. Environmental Microbiology, 15, 2082-2094. https://doi.org/10.1111/1462-2920.12130

Klaus, J. S., Janse, I., \& Fouke, B. W. (2011). Coral black band disease microbial communities and genotypic variability of the dominant cyanobacteria (CD1C11). Bulletin of Marine Science, 87, 795-821. https://doi.org/10.5343/bms.2010.1050

Kline, D. I., Kuntz, N. M., Breitbart, M., Knowlton, N., \& Rohwer, F. (2006). Role of elevated organic carbon levels and microbial activity in coral mortality. Marine Ecology Progress Series, 314, 119-125. https://doi.org/10.3354/meps314119

Kocasoy, G. (1989). The relationship between coastal tourism, sea pollution and public health: a case study from Turkey. Environmentalist, 9, 245-251. https://doi.org/10.1007/BF02241824

Köster, M, Dahlke, S., \& Meyer-Reil, L.A. (1997). Microbiological studies along a gradient of eutrophication in a shallow coastal inlet in the southern Baltic Sea (Nordrügensche Bodden). Marine Ecology Progress Series, 152, 27-39. https://doi.org/10.3354/meps152027 
Kuffner, I. B., \& Paul, V. J. (2001). Effects of nitrate, phosphate and iron on the growth of macroalgae and benthic cyanobacteria from Cocos Lagoon, Guam. Marine Ecology Progress Series, 222, 63-72. https://doi.org/10.3354/meps222063

Kuffner, I. B., \& Paul, V. J. (2004). Effects of the benthic cyanobacterium Lyngbya majuscula on larval recruitment of the reef corals Acropora surculosa and Pocillopora damicornis. Coral Reefs, 23, 455-458. https://doi.org/10.1007/s00338-004-0416-8

Kuffner, I. B., Walters, L. J., Becerro, M. A., Paul, V. J., Ritson-Williams, R., \& Beach, K. S. (2006). Inhibition of coral recruitment by macroalgae and cyanobacteria. Marine Ecology Progress Series, 323, 107-117. https://doi.org/10.3354/meps323107

Lane, D. R., Ready, R. C., Buddemeier, R. W., Martinich, J. A., Shouse, K. C., \& Wobus, C. W. (2013). Quantifying and valuing potential climate change impacts on coral reefs in the United States: Comparison of two scenarios. PloS One, 8(12), e82579.

https://doi.org/10.1371/journal.pone.0082579

Lapointe, B. E., \& Clark, M. W. (1992). Nutrient inputs from the watershed and coastal eutrophication in the Florida Keys. Estuaries and Coasts, 15, 465-476.

https://doi.org/10.2307/1352391

Ledlie, M. H., Graham, N. A. J., Bythell, J. C., Wilson, S. K., Jennings, S., Polunin, N. V. C., $\&$ Hardcastle, J. (2007). Phase shifts and the role of herbivory in the resilience of coral reefs. Coral Reefs, 26, 641-653. https://doi.org/10.1007/s00338-007-0230-1

Li, A., \& Reidenbach, M. A. (2014). Forecasting decadal changes in sea surface temperatures and coral bleaching within a Caribbean coral reef. Coral Reefs, 33, 847-861.

https://doi.org/10.1007/s00338-014-1162-1

Littler, M. M., Littler, D. S., Brooks, B. L., \& Lapointe, B. E. (2006). Nutrient manipulation methods for coral reef studies: a critical review and experimental field data. Journal of Experimental Marine Biology and Ecology, 336, 242-253.

https://doi.org/10.1016/j.jembe.2006.05.014

Livingston, R. J. (2001). Eutrophication Processes in Coastal Systems. Origin and Succession of Plankton Blooms and Effects on Secondary Production in Gulf Coast Estuaries. CRC Press, Boca Raton, FL 327 pp.

https://www.crcpress.com/Eutrophication-Processes-in-Coastal-Systems-Origin-and-Successi on-of-Plankton/Livingston/p/book/9780849390623

Macdonald, L. H., Anderson, D. M., \& Dietrich, W. E. (2007). Paradise threatened: land use and erosion on St. John, US Virgin Islands. Environmental Management, 21, 851-863. https://doi.org/10.1007/s002679900072

Mallin, M. A., Ensign, S. H., McIver, M. R., Shank, G. C., \& Fowler, P. K. (2001). Demographic, landscape, and meteorological factors controlling the microbial pollution of coastal waters. 185-193, In, The Ecology and Etiology of Newly Emerging Marine Diseases, Springer, Netherlands. https://doi.org/10.1007/978-94-017-3284-0_17 
Mallin, M. A., Williams, K. E., Esham, E. C., \& Lowe, R.P., (2000). Effect of human development on bacteriological water quality in coastal watersheds. Ecological Applications, 10, 1047-1056. https://doi.org/10.1890/1051-0761(2000)010[1047:EOHDOB]2.0.CO;2

Mao-Jones, J., Ritchie, K. B., Jones, L. E., \& Ellner, S. P. (2010). How microbial community composition regulates coral disease development. PLoS Biol, 8, e1000345.

https://doi.org/10.1371/journal.pbio.1000345

McComb, A. J. (1995). Eutrophic Shallow Estuaries and Lagoons. pp. 1-240, CRC Press, Boca Raton, FL.

https://www.crcpress.com/Eutrophic-Shallow-Estuaries-and-Lagoons/McComb/p/book/9780 849368394

Meesters, E. H., Bak, R.P.M., Westmacott, S., Ridgley, M., \& Dollar, S. (1998). A fuzzy logic model to predict coral reef development under nutrient and sediment stress. Conservation Biology, 12, 957-965. https://doi.org/10.1046/j.1523-1739.1998.96421.x

Moeller, M., Nietzer, S., Schils, T., \& Schupp, P. J. (2016). Low sediment loads affect survival of coral recruits: the first weeks are crucial. Coral Reefs, 35, 1-11. https://doi.org/10.1007/s00338-016-1513-1

Mouchka, M. E., Hewson, I., \& Harvell, C. D. (2010). Coral-associated bacterial assemblages: current knowledge and the potential for climate-driven impacts. Integrative and Comparative Biology, 50, 662-674. https://doi.org/10.1093/icb/icq061

Muthukrishnan, R., \& Fong, P. (2014). Multiple anthropogenic stressors exert complex, interactive effects on a coral reef community. Coral Reefs, 33, 911-921. https://doi.org/10.1007/s00338-014-1199-1

Naim, O. (1993). Seasonal responses of a fringing reef community to eutrophication (Reunion Island, Western Indian Ocean). Marine Ecology Progress Series, 99, 137-51. https://doi.org/10.3354/meps099137

Nemeth, R. S., \& Sladek-Nowlis, J. (2001). Monitoring the effects of land development on the near-shore reef environment of St. Thomas, USVI. Bulletin of Marine Science, 69, 759-775.

http://www.ingentaconnect.com/content/umrsmas/bullmar/2001/00000069/00000002/art0004 1 ?crawler=true

Nugues, M. M., \& Roberts, C. M. (2003). Coral mortality and interaction with algae in relation to sedimentation. Coral Reefs, 22, 507-516.

https://doi.org/10.1007/s00338-003-0338-x

Oleson, K. L., Falinski, K. A., Lecky, J., Rowe, C., Kappel, C. V., Selkoe, K. A., \& White, C. (2017). Upstream solutions to coral reef conservation: The payoffs of smart and cooperative decision-making. Journal of Environmental Management, 191, 8-18.

https://doi.org/10.1016/j.jenvman.2016.12.067

Otaño-Cruz, A., Montañez-Acuña, A. A., Torres-López, V. I., Hernández-Figueroa, E. M., \& 
Hernández-Delgado, E. A. (2017). Effects of changing weather, oceanographic conditions, and land uses on spatio-temporal variation of sedimentation dynamics along near-shore coral reefs. Frontiers in Marine Science, 4, 249. http://dx.doi.org/10.3389/fmars.2017.00249

Paddack, M. J., Reynolds, J.D., Aguilar, C., Appeldoorn, R.S., Beets, J., Burkett, E.W., Chittaro, P.M., Clarke, K., Esteves, R., Fonseca, A.C., \& Forrester, G.E. (2009). Recent region-wide declines in Caribbean reef fish abundance. Current Biology, 19, 590-595.

https://doi.org/10.1016/j.cub.2009.02.041

Pandolfi, J. M., Connolly, S. R., Marshall, D. J., \& Cohen, A. L. (2011). Projecting coral reef futures under global warming and ocean acidification. Science, 333, 418-422. https://doi.org/10.1126/science.1204794

Pastorok, R. A., \& Bilyard, G. R. (1985). Effects of sewage pollution on coral-reef communities. Marine Ecology Progress Series, 21, 175-189.

https://doi.org/10.3354/meps021175

Paul, V. J., Thacker, R. W., Banks, K., \& Golubic, S. (2005). Benthic cyanobacterial bloom impacts the reefs of South Florida (Broward County, USA). Coral Reefs, 24, 693-697.

https://doi.org/10.1007/s00338-005-0061-x

Pérez-Rosas, N. E., \& Hazen, T.C. (1988). In situ survival of Vibrio cholerae and Escherichia coli in tropical coral reefs. Applied and Environmental Microbiology, 54, 1-9. https://www.researchgate.net/publication/19876993_In_situ_survival_of_Vibrio_cholerae_an d_Escherichia_coli_in_topical_coral_reefs

Pérez-Rosas, N., \& Hazen, T. C. (1989). In situ survival of Vibrio cholerae and Escherichia coli in a tropical rain forest watershed. Applied and Environmental Microbiology, 55, 495-499. https://www.ncbi.nlm.nih.gov/pmc/articles/PMC202389/pdf/aem00106-0019.pdf

Philipp, E., \& Fabricius, K. (2003). Photophysiological stress in scleractinian corals in response to short-term sedimentation. Journal of Experimental Marine Biology and Ecology, 287, 57-78. https://doi.org/10.1016/S0022-0981(02)00495-1

Pratchett, M. S., Hoey, A. S., Wilson, S. K., Messmer, V., \& Graham, N. A. (2011). Changes in biodiversity and functioning of reef fish assemblages following coral bleaching and coral loss. Diversity, 3, 424-452. https://doi.org/10.3390/d3030424

Rabalais, N. N., Turner, R. E., Díaz, R. J., \& Justić, D. (2009). Global change and eutrophication of coastal waters. ICES Journal of Marine Science, 66, 1528-1537. https://doi.org/10.1093/icesjms/fsp047

Ramos-Scharrón, C. E. (2012). Effectiveness of drainage improvements in reducing sediment production rates from an unpaved road. Journal of Soil and Water Conservation, 67, 87-100. https://doi.org/10.2489/jswc.67.2.87

Ramos-Scharrón, C. E., Amador, J. M., \& Hernández-Delgado, E.A. (2012). An interdisciplinary erosion mitigation approach for coral reef protection - A case study from the eastern Caribbean. 127-160. In, Cruzado, A. (Ed.), Marine Ecosystems, ISBN: 
978-953-51-0176-5, InTech.

http://www.intechopen.com/articles/show/title/an-interdisciplinary-erosion-mitigation-approa ch-for-coral-reef-protection-a-case-study-from-the-eas

Ramos-Scharrón, C. E., Torres-Pulliza, D., \& Hernández-Delgado, E. A. (2015). Watershedand island-scale land cover changes in Puerto Rico (1930s-2004) and their potential effects on coral reef ecosystems. Science of the Total Environment, 506-507, 241-251. https://doi.org/10.1016/j.scitotenv.2014.11.016

Risk, M. J. (2014). Assessing the effects of sediments and nutrients on coral reefs. Current Opinion in Environmental Sustainability, 7, 108-117.

https://doi.org/10.1016/j.cosust.2014.01.003

Ritchie, K. B. (2006). Regulation of microbial populations by coral surface mucus and mucus-associated bacteria. Marine Ecology Progress Series, 322, 1-14.

https://doi.org/10.3354/meps322001

Rivera, S. C., Hazen, T. C. and Toranzos, G. A., (1988). Isolation of fecal coliforms from pristine sites in a tropical rain forest. Applied and Environmental Microbiology, 54, 513-517. https://www.ncbi.nlm.nih.gov/pmc/articles/PMC202482/pdf/aem00107-0241.pdf

Rogers, C. S. (1990). Responses of coral reefs and reef organisms to sedimentation. Marine Ecology Progress Series, 62, 185-202. https://doi.org/10.3354/meps062185

Rogers, C. S. (2013). Coral reef resilience through biodiversity. ISRN Oceanography, 2013; 739034: 1-18. http://dx.doi.org/10.5402/2013/739034

Rogers, C. S., \& Miller, J. (2006). Permanent 'phase shifts' or reversible declines in coral cover? Lack of recovery of two coral reefs in St. John, US Virgin Islands. Marine Ecology Progress Series, 306, 103-114. https://doi.org/10.3354/meps306103

Santamaria, J. \& Toranzos, G.A. (2003). Enteric pathogens and soil: a short review. International Microbiology, 6, 5-9.

https://www.researchgate.net/publication/10774089_Enteric_pathogens_and_soil_A_short_re view

Santiago-Rodríguez, T. M., Tremblay, R. L., Toledo-Hernández, C., González-Nieves, J. E., Ryu, H., Santo Domingo, J. W., \& Toranzos, G. A. (2012). Microbial quality of tropical inland waters and effects of rainfall events. Applied and Environmental Microbiology, 78, 5160-5169. https://doi.org/10.1128/AEM.07773-11

Santo Domingo, J. W., Fuentes, F. A., \& Hazen, T. C. (1989). Survival and activity of Streptococcus faecalis and Escherichia coli in petroleum-contaminated tropical marine waters. Environmental Pollution, 56, 263-281. https://doi.org/10.1016/0269-7491(89)90073-0

Scott, T. M., Rose, J. B., Jenkins, T. M., Farrah, S.M., \& Lukasik, J. (2002). Microbial source tracking: current methodology and future directions. Applied and Environmental Microbiology, 68, 5796-5803. https://doi.org/10.1128/AEM.68.12.5796-5803.2002 
Sekar, R., Kaczmarsky, L. T., \& Richardson, L. L. (2008). Microbial community composition of black band disease on the coral host Siderastrea siderea from three regions of the wider Caribbean. Marine Ecology Progress Series, 362, 85-98. https://doi.org/10.3354/meps07496

Shelton, A. J., \& Richmond, R. H. (2016). Watershed restoration as a tool for improving coral reef resilience against climate change and other human impacts. Estuarine, Coastal and Shelf Science, 183, 430-437. https://doi.org/10.1016/j.ecss.2016.06.027

Sladek-Nowlis, J., Roberts, C. M., Smith, A. H., \& Siirila, E. (1997). Human-enhanced impacts of a tropical storm on nearshore coral reefs. Ambio, 26, 515-521. https://www.researchgate.net/publication/281297021_Human-enhanced_impacts_of_a_tropic al_storm_on_nearshore_reefs

Smith, T. B., Nemeth, R. S., Blondeau, J., Calnan, J. M, Kadison, E., \& Herzlieb, S. (2008). Assessing coral reef health across onshore to offshore gradients in the US Virgin Islands. Marine Pollution Bulletin, 56, 1983-1991. https://doi.org/10.1016/j.marpolbul.2008.08.015

Stewart, J. R., Gast, R.J., Fujioka, R.S., Solo-Gabriele, H.M., Mschke, J.S., Amaral-Zettler, L.A., del Castillo, E., Polz, M.F., Collier, T.K., Strom, M.S., Sinigalliano, C.D., Moeller, P.D.R., \& Holland, A.F. (2008). The coastal environment and human health: microbial indicators, pathogens, sentinels and reservoirs. Environmental Health 7(Suppl 2), S3-S16. https://doi.org/10.1186/1476-069X-7-S2-S3

Storlazzi, C. D., Norris, B. K., \& Rosenberger, K. J. (2015). The influence of grain size, grain color, and suspended-sediment concentration on light attenuation: Why fine-grained terrestrial sediment is bad for coral reef ecosystems. Coral Reefs, 34, 967-975. https://doi.org/10.1007/s00338-015-1268-0

Sturm, P., Viqueira-Ríos, R., Meyer-Comas, L., Hernández-Delgado, E.A., González-Ramos, C., Monta-ez-Acu-a, A., \& Otaño-Cruz, A. (2014). Culebra Community Watershed Action Plan for Water Quality and Coral Reefs. Technical Report submitted to NOAA, Silver Spring, MD. 76 pp. https://www.dropbox.com/s/xxmi9xtg4wli494/Culebra\%20final.pdf?dl=0

Szmant, A. M. (2002). Nutrient enrichment on coral reefs: is it a major cause of coral reef decline? Estuaries, 25, 743-766. https://doi.org/10.1007/BF02804903

Tomascik, T. (1990). Growth rates of two morphotypes of Montastrea annularis along a eutrophication gradient, Barbados, W.I. Marine Pollution Bulletin, 21, 376-381.

Tomascik, T. (1991). Settlement patterns of Caribbean scleractinian corals on artificial substrata along a eutrophication gradient, Barbados, West Indies. Marine Ecology Progress Series, 77, 261-269. https://doi.org/10.3354/meps077261

Tomascik, T., \& Sander, F. (1985). Effects of eutrophication on reef-building corals. I. Growth rate of the reef-building coral Montastrea annularis. Marine Biology, 87, 132-155. https://doi.org/10.1007/BF00539422

Tomascik, T., \& Sander, F. (1987a). Effects of eutrophication on reef-building corals. II. Structure of scleractinian coral communities on fringing reefs, Barbados, West Indies. Marine 
Biology, 94, 53-75. https://doi.org/10.1007/BF00392900

Tomascik, T., \& Sander, F. (1987b). Effects of eutrophication on reef-building corals. III. Reproduction of the reef-building coral Porites porites. Marine Biology, 94, 77-94. https://doi.org/10.1007/BF00392901

Tomasko, D. A., Dawes, C. J., \& Hall, M. O. (1996). The effects of anthropogenic nutrient enrichment on turtle grass (Thalassia testudinum) in Sarasota Bay, Florida. Estuaries and Coasts, 19, 448-456. https://doi.org/10.2307/1352462

Tracy, A. M., Koren, O., Douglas, N., Weil, E., \& Harvell, C. D. (2015). Persistent shifts in Caribbean coral microbiota are linked to the 2010 warm thermal anomaly. Environmental Microbiology Reports, 7, 471-479. https://doi.org/10.1111/1758-2229.12274

Vega Thurber, R. L., Burkepile, D. E., Fuchs, C., Shantz, A. A., McMinds, R., \& Zaneveld, J. R. (2013). Chronic nutrient enrichment increases prevalence and severity of coral disease and bleaching. Global Change Biology, 20, 544-554. https://doi.org/10.1111/gcb.12450

Vega Thurber, R., Burkepile, D. E., Correa, A. M., Thurber, A. R., Shantz, A. A., Welsh, R., Pritchard, C., \& Rosales, S. (2012). Macroalgae decrease growth and alter microbial community structure of the reef-building coral, Porites astreoides. PLoS One, 7, p.e44246. https://doi.org/10.1371/journal.pone.0044246

Veron, J. E. N., Hoegh-Guldberg, O., Lenton, T. M., Lough, J. M., Obura, D. O., Pearce-Kelly, P., Sheppard, C. R., Spalding, M., Stafford-Smith, M.G., \& Rogers, A. D. (2009). The coral reef crisis: The critical importance of $<350 \mathrm{ppm} \mathrm{CO}_{2}$. Marine Pollution Bulletin, 58, 1428-1436. https://doi.org/10.1016/j.marpolbul.2009.09.009

Waterhouse, J., Brodie, J., Lewis, S., Audas, D. M. (2016). Land-sea connectivity, ecohydrology and holistic management of the Great Barrier Reef and its catchments: time for a change. Ecohydrology \& Hydrobiology, 16, 45-57.

https://doi.org/10.1016/j.ecohyd.2015.08.005

\section{Glossary}

H'c: Shannon-Weaver species diversity index based on coral percent cover.

J'c: Pielou's species evenness based on coral percent cover.

\section{Copyright Disclaimer}

Copyright for this article is retained by the author(s), with first publication rights granted to the journal.

This is an open-access article distributed under the terms and conditions of the Creative Commons Attribution license (http://creativecommons.org/licenses/by/3.0/). 